\title{
LOS COMIENZOS EN LA PRODUCCIÓN DEL CINE DOCUMENTAL CHAQUEÑO: CINE CIENTÍFICO Y RELACIONES DE ALTERIDAD EN LOS AÑOS 60 Y 70
}

\author{
The beginnings of documentary film production in chaco: scientific cinema and \\ otherness relationships in the $60 \mathrm{~s}$ and $70 \mathrm{~s}$
}

Franco Passarelli*

ORCID: 0000-0002-3582-8102

\begin{abstract}
Resumen
El presente artículo discute acerca de la producción y la representación en los primeros films documentales realizados por cineastas de la provincia del Chaco, desde los comienzos de los años 60 hasta 1976. El análisis se centra en primera instancia en el proceso de producción de dichas películas, donde se destaca que hubo un circuito de producción incipiente en la ciudad de Resistencia, sostenido principalmente a partir de los vínculos sociales entre los realizadores y el fomento de la Universidad Nacional del Nordeste (UNNE). Por el lado de las representaciones, se plantean dos grandes categorías de análisis como son el "cine científico" y el "cine de la diferencia" (alteridad), a partir de los sentidos compartidos entre los films. Los casos de los realizadores a trabajar son los de Ángel Fernández Pissano, Juan Carlos Vidarte, Jorge Omar Ott, Jorge Castillo e Isaac Belsky, quienes produjeron aproximadamente veinticinco cortometrajes en la mencionada época. El estudio sobre estas películas se torna relevante para recuperar un material que ha estado invisibilizado en la historia del cine argentino y, a la vez, contribuir a la memoria histórica de la región del Nordeste, desde sus propios realizadores.
\end{abstract}

$<$ Cine chaqueño $><$ Procesos de producción $><$ Cine científico $><$ Alteridad $>$

\begin{abstract}
:
This article discusses about production and representation on the first documentary films made by filmmakers of the province of Chaco, from the early 1960s to 1976. The analysis focuses primarily on production processes, where it stands out that there was an incipient production circuit in the city of Resistencia, sustained mainly by the social networks between the filmmakers and the promotion of the Universidad Nacional del Nordeste (UNNE). In what regards representations, two major categories of analysis are proposed, such as "scientific cinema" and "cinema of difference", based on the meanings shared between by the films. The cases of the filmmakers to work with are Ángel Fernández Pissano, Juan Carlos Vidarte, Jorge Omar Ott, Jorge Castillo, and Isaac Belsky, who produced approximately twenty-five short films in the aforementioned period. The study of these films becomes relevant to recover a material that has been invisible in the history of the Argentine cinema and, at the same time, contribute to the historical memory of the Northeast region from its own filmmakers.

$<$ Chaco cinema $><$ Production processes $><$ Scientific cinema $><$ Otherness $>$
\end{abstract}

Recibido: 28/09/2020//Aceptado: 25/11/2020

\footnotetext{
* Instituto de Investigaciones Geohistóricas (UNNE/CONICET). Facultad de Artes, Diseño y Ciencias de la Cultura).fpassarelli16@gmail.com
} 
Passarelli. Los comienzos en la producción del cine documental chaqueño: cine científico y relaciones de alteridad...

\section{Introducción}

El propósito de este artículo es brindar un panorama general acerca de las primeras películas producidas por cineastas chaqueños desde comienzos de los años 60 hasta 1976, dando cuenta de algunas dinámicas sociales, culturales e históricas que atraviesan conjuntamente a los films y a sus creadores. ${ }^{1}$ Durante esta época se realizaron aproximadamente veinticinco cortometrajes documentales, cuyos directores fueron Ángel Fernández Pissano, Juan Carlos Vidarte, Jorge Omar Ott, Jorge Castillo e Isaac Belsky, los cuales podrían llegar a ser considerados como parte de las primeras experiencias en la región. ${ }^{2}$ Sin embargo, poco se ha estudiado sobre este periodo (y sobre el cine chaqueño en general), a excepción de la única obra escrita que sistematiza la filmografía de estos primeros realizadores, llamada Cine Argentino e Identidad Cultural publicada por el psicólogo, cineasta y gestor cultural chaqueño Jorge Castillo en el año 2003. El mencionado libro se presenta como un documento fundamental para indagar sobre las producciones y los realizadores de dicho momento histórico, a partir del conocimiento de "primera mano" del escritor (dado que él mismo es uno de los cineastas pioneros como veremos a continuación) y de su gran trabajo de recopilación de información y de material audiovisual reunidos en su base de datos. Es importante remarcar también, las notas escritas por la prensa gráfica del momento, que han servido para brindar detalles importantes sobre los cineastas y sus obras. Si bien no constituyen un conocimiento especializado en el marco académico, los artículos periodísticos publicados en los diarios locales son antecedentes importantes sobre el tema, como veremos a lo largo de este artículo. Por último, es de interés mencionar que en la actualidad están surgiendo nuevos trabajos e investigadores que impulsan la producción de una crítica audiovisual especializada en y sobre la provincia, la cual ha desplegado diferentes perspectivas en los últimos años (Barrios y Arancibia, 2018; Bradford, 2018; Cossalter, 2019; Fernández Silva, 2020; Soler, 2017). ${ }^{3}$

El objetivo del presente artículo es indagar acerca de cuáles fueron las continuidades y las diferencias tanto en el proceso de producción como en el modo de representación, comparando las mencionadas pioneras experiencias en el ámbito chaqueño. ${ }^{4}$ Con este fin, dividimos al análisis en dos dimensiones, la primera relacionada a la producción de los films, y la segunda, enfocada en los modos de representación de

${ }^{1}$ La presente investigación forma parte del Proyecto de Unidad Ejecutora (PUE) Región NEA y políticas públicas (2017- 2021) perteneciente al Instituto de Investigaciones Geohistóricas (IIGHI- CONICET/ UNNE) y del PICT Cartografia y estudio histórico de los procesos cinematográficos en Argentina (18962016), Facultad de Filosofía y Letras, UBA.

2 Las únicas películas contemporáneas a la época tratada son Misiones, tierra colorada (Vier y Mirone, 1967) y De Misiones al país (Vier y Mirone, 1969-1970). Además de la prematura ficción de Patrulla Norte (Echenique, 1951), de Formosa.

3 Aquí cabe destacar también a la revista digital Cinetosis, que publica trabajos sobre crítica audiovisual producida desde la región del NEA.

${ }_{4}$ El análisis de los films se ve sesgado por el punto ciego que tiene todo trabajo con archivos fílmicos, ya que más de la mitad se encuentran perdidos. Gran parte de este problema se debe a que hay un vacío en los archivos municipales, provinciales, regionales y nacionales. Sin embargo, a partir del abordaje simultáneo con entrevistas a los realizadores, artículos periodísticos, fotografías y otras fuentes primarias, pudimos reconstruir algunos datos sobre estas obras. 
los mismos. Nos centramos inicialmente en el mapeo de las biografías de los directores, partiendo de la hipótesis que hubo un circuito de producción incipiente en la ciudad de Resistencia, sostenido principalmente a partir de los vínculos sociales entre los realizadores y del fomento de la Universidad Nacional del Nordeste (UNNE). Dicha hipótesis se fundamenta en algunas características comunes, como la polifuncionalidad de los realizadores y el intercambio de roles en las producciones de los cortometrajes (por ejemplo, algunos aparecían como directores en un film y sonidistas en otro), la autoformación (la enseñanza de la técnica entre ellos), el trabajo interdisciplinario (en la producción participaban profesionales de diferentes áreas académicas) y los encuentros en los espacios de exhibición.

Luego, en la siguiente instancia del artículo, proponemos dos categorías cinematográficas como un intento inicial por delinear sentidos compartidos entre los films, a partir del análisis del empleo de las herramientas audiovisuales. ${ }^{5}$ Distinguimos de este modo una primera categoría denominada "cine científico", que corresponde a los cortometrajes técnicos, de educación y divulgación científica, donde se utilizó el medio audiovisual como herramienta didáctica. Dichas producciones, tomando elementos del modo de representación del documental expositivo (Nichols, 1997), se caracterizaron por la voz over guiando la narración y las imágenes como complemento ilustrativo o contrapunto, construyendo un discurso de verdad a partir de la aparición de los científicos o instituciones universitarias en pantalla. Estos cortometrajes eran destinados a un público general, exhibiéndose en hospitales, campos, escuelas, universidades y centros sociales de la provincia y de la región. El cine científico producido en el Chaco, atrapaba a los espectadores a partir de su reconocimiento en la pantalla y de su argumentación clara y concisa con principio, problema y final (narrativa lineal). No había margen para otras interpretaciones y el mensaje educativo se dirigía directo al espectador.

En la segunda categoría hacemos foco en realizaciones que abordan aspectos culturales y sociales de la sociedad chaqueña, a las cuales llamamos "cine de la diferencia". Analizamos el punto de vista de la narración y el manejo del sonido (principalmente a partir del análisis de la voz over y voz en off) ${ }^{6}$ y nos detenemos en la construcción de las relaciones de alteridad entre el realizador y el sujeto filmado. Se trata de investigar el complejo juego de relaciones entre cámara, sujeto filmado y realizador, los cuales

\footnotetext{
5 Las dos categorías que proponemos son meramente analíticas intentando escapar de las definiciones ontologizantes (Bovisio, 2013) y reduccionistas que anclan una película con una categoría. Con esto nos referimos a que no se trata de pensar en categorías cerradas, taxonómicas e inmutables, sino todo lo contrario. Son intentos por perfilar elementos que se repiten en los cortometrajes pero, no por eso, dejarlos fijados a dichas categorías. Veremos cómo las dos categorías cinematográficas que discutimos en este artículo tienen sus límites y sus posibilidades, otorgándonos herramientas analíticas para la investigación, pero sin perder de vista que las películas no responden a las categorías por sus características inmanentes sino, por cómo las miramos como investigadores.

6 Ambos tipos de "voces" se diferencian fundamentalmente por formar parte o no de la diégesis. Veremos cómo en el cine documental chaqueño de esta primera época ha predominado la voz over, caracterizada por una locución desencarnada de la diégesis, mientras que en el caso de En Busca de San La Muerte (Ott y M. y Vedia, 1972) los relatos que escuchamos se corporizan en el relato del personaje principal, figurando una voz en off.
} 
Passarelli. Los comienzos en la producción del cine documental chaqueño: cine científico y relaciones de alteridad...

quedaron inmersos en un mismo contexto histórico. Los puntos más relevantes en los que nos centramos son las relaciones de poder, los cursos históricos sobre la producción de realidad y los discursos a partir de reconocerse o no en la imagen del "Otro". Muchas de las estrategias del "cine científico" continúan en estos films, pero aplicados al campo social y cultural. Así veremos cómo en este apartado, las películas intentan sumar elementos a la idea de una "identidad chaqueña".

Tomamos en consideración el periodo que inicia a comienzos de los años 60 y finaliza en 1976, ya que dichos años fueron significativos para el proceso de "regionalización" del Nordeste Argentino (NEA), que se impuso como plan estratégico desde el gobierno central, a partir del decreto del presidente de facto Juan Carlos Onganía en 1967 (Leoni y Solís Carnicer, 2018). Con esta resolución, las provincias de Corrientes, Chaco, Formosa y Misiones quedaban conformadas como una unidad funcional y administrativa bajo "el deseo de planificación social, reforma económica y programas de desarrollo que requieren un nivel intermedio entre los niveles nacional y local" (Leoni, 2010, s.p). De este modo, la región NEA es creada por el poder central, como parte de un proceso de reorganización en la planificación estatal. Sin embargo esta idea no era nueva en las provincias ya que la creación de la Universidad Nacional del Nordeste (UNNE) en 1956, marca un antecedente fundamental para la instauración de esta gran región, reforzando dicha noción que venía desde los años $40 .{ }^{8}$ Inmersos en este contexto, "los intelectuales han jugado un papel determinante en la tarea simbólica de construcción del regionalismo" (Leoni y Solís Carnicer, 2018, p. 34) fijando de contenido cultural, histórico y social a los heterogéneos contornos del NEA. Así es que aparecen figuras fundamentales como el escritor Guido Miranda ${ }^{9}$, entre otros intelectuales locales de la época, que intentan unir el carácter identitario regional con el provincial. Dentro de este contexto y formando parte del grupo de pensadores (ya que se vinculaban socialmente entre ellos), aparecen los cineastas chaqueños como contribución a este fenómeno, pero manteniendo algunas diferencias.

Veremos que el sentido de pertenencia de los realizadores se vincula más a lo provincial que a lo regional en estos primeros realizadores. Benedetti afirma que las provincias son "las unidades subnacionales que definen territorialidades y que entran en conflicto sistemáticamente con la territorialidad del estado nacional" (2008, p. 30) y destaca algunos provincialismos marcados como el correntino, el neuquino o el salteño. De este modo, "la construcción de una narrativa sobre las regiones geográficas desde el discurso oficial del estado nacional, puede pensarse como una estrategia simbólica para diluir las fuertes territorialidades provinciales" (Benedetti, 2008, s.p). Analizaremos

\footnotetext{
7 Es importante remarcar la diferencia entre "regionalización" y "regionalismo". El primero se refiere a "los esfuerzos estatales a través de un amplio rango de medidas para integrar la región dentro del estado y controlarla", mientras que la segunda, "representa el esfuerzo por crear una conciencia y una ideología política dentro o en nombre de la región" (Leoni y Solís Carnicer, 2018, p. 33).

8 Por ejemplo se discutía con las ideas de "región misionera, región chaqueña, Litoral argentino, Mesopotamia basados en criterios geográficos e históricos" (Leoni y Solís Carnicer, 2018, p. 33).

9 Cabe señalar que Guido Miranda ha participado como guionista en algunos de los films que desarrollaremos a continuación.
} 
cómo en las películas producidas en esta época (especialmente en las que llamamos "cine de la diferencia"), hay un fuerte interés por destacar rasgos característicos del carácter colectivo provincial, a la vez que se problematizan sus límites y sus posibilidades. Esta tensión entre lo regional y lo provincial, va a ser lo subyacente a la narrativa de todas las películas que tomamos para el análisis.

El estudio que aquí presentamos parte del campo de los estudios audiovisuales, en la interacción entre las Ciencias Sociales y la Historia del Arte, con el fin de poner en discusión representaciones, formas de la memoria e imaginarios sobre la provincia del Chaco, la región y la nación. Preguntarse sobre el cine chaqueño y el cine regional es preguntarse por quiénes hablan, de qué forma lo hacen, bajo qué discursos y cuáles son sus medios. Sostenemos que estudiar la filmografía de los realizadores chaqueños implica una visibilización en diferentes niveles desde sus aportes y sus dificultades. Por un lado, se trata de dar a conocer nuevos directores y equipos de producción dentro del campo de la "cinematografía nacional", la cual ha estado históricamente diseñada por las obras producidas en y desde Buenos Aires. Se apunta a difundir nuevas películas, modos de producción y formas de circulación, que han quedado fuera de la órbita de la capital nacional. Paralelamente, este fenómeno de invisibilización también ha sucedido dentro de la misma región, donde los mencionados films han quedado ocultos, así es que el reconocimiento se plantea en un doble movimiento tanto dentro del NEA como por fuera. Por otro lado, se trata de identificar y revalorar el papel que ha tenido la UNNE en la producción de cine, ignorado por los estudios fílmicos hasta el momento. Quizás por lo poco que se conoce de su filmografía, por el desconocimiento de los investigadores con respecto a la región, por no haber creado una carrera de artes audiovisuales o porque no ha desplegado formas alternativas del lenguaje audiovisual ni realizadores reconocidos, la UNNE ha quedado fuera del círculo de las Universidades Nacionales que produjeron cine durante los 60 y 70. Sin embargo sus producciones fueron numerosas y dieron un gran impulso a los cineastas locales, los cuales en su mayoría trabajaron dentro de la Universidad. ${ }^{10}$ Por último, resaltar que al estudiar los films chaqueños, damos cuenta también que los canales de difusión son muy escuetos y los fomentos a la producción casi nulos.

\section{Los realizadores y sus redes. Biografías cruzadas}

Las primeras experiencias chaqueñas de audiovisuales documentales que vamos a describir no llegaron a constituir una industria, ni estuvieron cerca de ello. Muy lejos de contar con una gran infraestructura ni con grandes presupuestos, dichos cortometrajes se lograron a partir de la colaboración de muchos de sus participantes. Si bien no conformaron un grupo ni un movimiento artístico entre los realizadores, estas producciones fueron algo más que experiencias aisladas y articularon un incipiente circuito de producción relativamente estable en la ciudad de Resistencia. Para sostener

\footnotetext{
${ }^{10}$ Además, en algunas de estas producciones la participación del Consejo Nacional de Investigaciones Científicas y Técnicas (CONICET) fue clave, dando cuenta también del interés del desarrollo de estrategias audiovisuales en la región.
} 
Passarelli. Los comienzos en la producción del cine documental chaqueño: cine científico y relaciones de alteridad...

esta idea nos basamos en varios argumentos que dan cuenta de un sistema de relaciones sociales preexistente. Por un lado, el intercambio de roles entre realizadores, guionistas, camarógrafos, sonidistas, productores y proyeccionistas fue una constante en casi todos los films. Vamos a ver a lo largo de este apartado cómo muchos de los participantes del equipo de producción aparecen en los títulos de las diferentes películas, pero con labores trocados en ellas. Este trabajo generalmente no era remunerado y la motivación era el hecho de ayudar a un colega y aprender un poco más sobre la técnica. Apropósito de la enseñanza y el aprendizaje (esto tiene que ver con el segundo argumento), en toda la región no hubo escuelas de artes audiovisuales hasta los años recientes. Por lo tanto, algunos tuvieron que tomar pequeños cursos de fotografía y cinematografía en Buenos Aires o Rosario, aunque la mayoría se formó de manera autodidacta o aprendiendo de otros cineastas. Estas instancias de autoformación de carácter informal entre los mismos realizadores contribuyeron al sostén de las producciones. Además, las películas no hubieran sido posible sin la colaboración de profesionales de otras áreas como la literatura, el teatro, la historia, la antropología, la arquitectura y la filosofía. Esto daba como resultado procesos de producción interdisciplinarios, con formas audiovisuales variadas y temáticas diversas, pero siempre ancladas a problemáticas locales. En síntesis, los cortometrajes fueron producidos en diferentes redes de relaciones, donde el realizador era un actor más dentro de las mismas. Los realizadores interactuaban entre ellos a partir de las diferentes instancias de producción, pero además, conformaban grupos, intercambiaban material, exhibían en determinados espacios y allí volcaban sus ideas. Las redes sociales que se establecieron entre los realizadores y equipo de producción, lograron que dichas experiencias se lleven a cabo y se conserven, algunas de ellas, hasta nuestros días.

El primer cineasta chaqueño, reconocido por los mismos realizadores, es Ángel Fernández Pissano. Él nació en la provincia de Misiones, pero en su juventud se trasladó a Resistencia. Pissano tenía experiencia en el campo de la realización ya que había participado como ayudante del director de fotografía en la renombrada película Prisioneros de la tierra (Sofficci, 1939), antes de mudarse al Chaco. Su dedicación en el estudio técnico de la imagen, perfeccionando cada vez más sus lentes, cámaras y equipos, hizo que se convierta en un gran referente para los audiovisualistas jóvenes del momento. Según Castillo (2003), Fernández Pissano trabajó en la UNNE a mediados de los 60 como creador y organizador de las diapositivas, a la vez que hizo de corresponsal para el noticiero Reporter ESSO y luego viajó a Capital Federal para ser empleado de los famosos laboratorios Alex. Fernández Pissano tenía un gran archivo de imágenes del Chaco que había tomado él mismo y que hasta ahora se encuentran perdidas. Además había montado un laboratorio de fotografía muy conocido en el centro de Resistencia, que luego fue comprado por Jorge Omar Ott como veremos más adelante. En el año 1962 realiza, junto con el polifacético Raúl Cerrutti ${ }^{11}$, el cortometraje Bajo el signo

\footnotetext{
11 "Folklorólogo" (como se le llamaba en aquel momento a quienes tenían un amplio conocimiento sobre las "culturas", en este caso las del Chaco), músico, escritor y productor. Acompañó varios procesos de realización de estos primeros films, tanto en la ejecución como en la musicalización.
} 
del camino $^{12}$ y al año siguiente El camino de la verdad. Esta segunda película, que aún se conserva gracias al trabajo de Jorge Castillo, aborda la lepra y su tratamiento. El proceso de producción de El camino de la verdad se puede reconstruir en parte, por una nota que publicó Claudio Domínguez (actor del film) en 1995 en el diario Norte y que recoge Castillo (2003) en su libro. Allí describe cómo la idea de la película comenzó en el bar Sorocabana de Resistencia donde estaban reunidos "los amigos de siempre" (sic) cuando Cerrutti les comentó su intención de filmar una película sobre la lepra con ellos como participantes:

Ya tengo casi completo el equipo. Fernández Pissano, camarógrafo; iluminador, el "Negro" Medina (maquinista del cine-teatro S.E.P); sonidos y efectos especiales "Totó" Borfitz. "Coco" Celada interpretará al enfermo y de su esposa hará Mary Caponi. Sólo me falta el médico. Aquí paró su exposición y entró a mirarme de arriba a abajo: me estudiaba. Claudio ¿Te animas? Tu rostro serio siempre da el perfil del actor que necesito, el personaje a componer debe ser creíble naturalmente (Domínguez, 1995 en Castillo, 2003, p. 104).

Las redes de confianza entre los participantes de la película sumado al auspicio del Patronato de Leprosos (como se llamaba en esa época) y del Subdepartamento de la Lepra (Ministerio de Salud Pública del Chaco), posibilitaron su producción. ${ }^{13}$ Dicha asociación brindó sus instalaciones ${ }^{14}$ y financió el proyecto a través de un préstamo del Banco del Chaco. El asesoramiento profesional estuvo a cargo del Dr. Manuel María Giménez, quien fue el director del Patronato por más de cuatro décadas. La película tuvo un gran éxito y circuló tanto en el país como en el exterior. Sus canales de distribución estaban conectados principalmente por los patronatos en las diferentes provincias y muchas de sus proyecciones eran hechas en escuelas, centros de salud y espacios públicos, así como en grandes cines. Unos años más tarde fue pasada a video y proyectada para todo el país por el canal público ATC.

A mediados de los años cincuenta llega a Resistencia el santafesino Juan Carlos Vidarte, quien en 1958 va a ingresar en el Departamento de Audiovisuales de la $\mathrm{UNNE}^{15}$ y va a permanecer en dicha institución por más de cuarenta años. Vidarte es

\footnotetext{
${ }^{12}$ Este film, perdido en la actualidad, fue producido por la provincia del Chaco y trata sobre la red de caminos que construyó el gobernador Anselmo Zoilo Duca, durante sus años de gestión (1958- 1962).

${ }^{13}$ Otras organizaciones que aparecen como colaboradoras son el Cine Teatro S.E.P., Aerolíneas Argentinas (Agencia Resistencia), Biblioteca Lynch Arribálzaga, Escuela Nacional Benjamín Zorrilla, Diario El Territorio, L.T. 5 Radio Chaco y "pueblo de Resistencia".

${ }^{14}$ Según cuenta Cerrutti en una entrevista televisiva en el programa Nuestro Cine (1985), muchas de las escenas interiores se filmaron en el dispensario del Patronato (calle Ameghino y 4, Resistencia). En ese lugar, tanto Fernández Pissano como él, hicieron una observación "paso a paso de cómo actuaba el médico frente al enfermo", hasta el punto de hacerse pasar por médicos ellos mismos. Ahí "pudimos obtener todos los detalles, todo el mundo, todo el contexto que rodea a un consultorio y fundamentalmente a este tipo de enfermedad de la piel" (Fragmento de entrevista, Nuestro Cine, 1985).

${ }^{15}$ Unos años después este Departamento va a pasar a ser la Sección Foto- Cinematografía del Departamento
} 
Passarelli. Los comienzos en la producción del cine documental chaqueño: cine científico y relaciones de alteridad...

una figura clave del cine chaqueño ya que ha filmado cerca de cuarenta películas, a la vez que ha enseñado la técnica y promovido espacios de exhibición. Sus primeros dos cortometrajes datan del año 1955, llamados Cosecheros (Vidarte, 1955) y Niños de la Sarmiento (Vidarte, 1955). A partir de su ingreso a la UNNE, el realizador va a comenzar a producir una serie de films técnicos, vinculados a la problemática de los suelos, en coordinación con el Instituto Agrotécnico de la UNNE (los cuales analizaremos en el siguiente apartado). ${ }^{16}$ Las películas técnicas de Vidarte circularon por universidades, escuelas y algunos festivales, obteniendo premios y menciones. También filmó algunas otras producciones, como Operativo titus (Vidarte, 1967) y Carnaval para vivir (Vidarte, 1969), pero su más reconocida obra llegaría en el año 1972 con Oscar Medina, artesano (Vidarte, 1972), premiada por el Fondo Nacional de las Artes.

Además de estar en contacto con Fernández Pissano y otros cineastas, Vidarte mantenía constante relación con los intelectuales locales de la época como Guido Miranda, Carlos Primo López Piacentini, José García Pulido y otras figuras chaqueñas del ámbito del arte, como los hermanos Boglietti. Es significativo el café Sorocabana, ya que ese era el punto de encuentro de muchos de ellos. Comenta Vidarte en una nota periodística "En aquellos años, nos reuníamos todas las noches en el Sorocabana, hasta que cerraba sus puertas; y seguíamos, en los bancos de la plaza, con nuestras discusiones (...) Estudiábamos desde Marx a Nietzsche, entre tantos clásicos de la época" (2006, p. 8$)^{17}$. Al mismo tiempo que se sucedían estos cafés filosófico-sociales, Vidarte creó junto con León y Gerardo "Pepe" Bentolila, el cine-club "Cine Arte Resistencia". Allí se exponían grandes clásicos del cine alternativo de la época, donde participaban los mismos realizadores.

El tercer cineasta en el que nos vamos a detener es Jorge Omar Ott, un gran referente del cine local. Ott nació en Resistencia en 1938 y, después de terminar sus estudios secundarios, se instaló en Buenos Aires durante dos años para aprender electrónica. A principios de los 60 en su vuelta al Chaco, se inscribe en la carrera de Derecho en la UNNE pero la deja para ingresar en la Dirección del Aborigen, recorriendo los territorios de toda la provincia durante seis años aproximadamente. A mediados de los 60, decide retomar sus estudios en Derecho y allí conoce a Fernández Pissano, quien trabajaba en la Universidad y a la vez, tenía el laboratorio de fotografía. Motivado por Fernández Pissano, Ott decide dejar la Dirección del Aborigen, comprarle el estudio al mencionado realizador y dedicarse a la producción de imágenes fotográficas. Con el comercio en un principio se dedicó a la fotografía social, pero luego cuando surgieron las "cámaras de mano" (más baratas y rápidas), se convirtió sólo en un laboratorio de revelado. A finales de los 60 el laboratorio no funcionaba bien económicamente, así que decide venderlo y presentarse en un concurso como administrativo de la Universidad.

de Extensión Universitaria y Ampliación de Estudios.

${ }^{16}$ A propósito del equipo de producción de estos films, Vidarte señala que "el grupo que me acompaña está integrado por técnicos del Chaco magníficamente capacitados empresa" (Proyección de la labor de Vidarte: cineasta integrado a nuestro Chaco, 26 de Noviembre de 1969, s.p.), manifestando su reconocimiento a la pertenencia de los sujetos.

${ }^{17}$ El documentalismo que todavía nos UNNE. 14 de septiembre de 2006. Norte. p. 8 
A partir de su conocimiento en electrónica y de su experiencia en el laboratorio de fotografía, ingresa a la UNNE, y se incorpora al Departamento de Extensión Universitaria y a la Facultad de Humanidades. Ott era el encargado de un pequeño laboratorio de imágenes, donde produjo una gran cantidad de material: acompañaba con el apoyo fotográfico a proyectos de investigación, realizaba subtítulos de películas extranjeras, creaba diapositivas para las cátedras y armaba ciclos de cine. Además, durante esos años, estudia fotografía en Buenos Aires y conoce a Jorge Prelorán, quien fue uno de sus grandes referentes. En 1972, bajo el auspicio del Fondo Nacional de Artes y de la Facultad de Arquitectura de la UNNE filma, junto con el arquitecto Mario Molina y Vedia y el asesoramiento del antropólogo José Miranda Borelli, En busca de San La Muerte (Ott y Molina y Vedia, 1972). Este film participó de varios festivales y tuvo una amplia difusión por todo el país. Como parte de su trabajo en la UNNE también realizó algunos cortometrajes para el Instituto de Medicina Regional (bajo la dirección del Dr. Jorge Yanovsky) y la Facultad de Medicina. Ambos films, Vivir puede ser hermoso (Ott, 1975) y Docencia e investigación en el complejo técnico social (Ott, 1975) son de carácter técnico acerca de cómo se puede detectar el mal de chagas. En el primero de ellos, participa como camarógrafo "Cacho" Belsky, a quien veremos más adelante. Ya en el último año antes del Golpe Militar de 1976, filmó varias entrevistas en Ituzaingó para llevar a cabo un largometraje sobre el impacto de la represa de Yacyretá, pero el proyecto quedó trunco con la llegada del gobierno de facto. ${ }^{18}$

Jorge Castillo, nació en Resistencia en el año 1946 y estudió psicología en Rosario, donde participó de actividades artísticas como el canto coral y colaboró activamente en la organización del grupo artístico independiente Arteón. Allí despertó su vocación por las artes audiovisuales, comenzando a filmar sus primeros cortometrajes. Su obra cubre un abanico de formas como la ficción, el documental, la experimentación y la animación. Todas sus producciones de la época de los años 60 y 70 se realizaron en Súper 8 mm ${ }^{19}$ y fueron guionadas, producidas, filmadas y editadas por él mismo. Además de ser un prolífico realizador, Castillo también ha sido un exhaustivo investigador y archivista del cine chaqueño. Conserva y exhibe en el Centro Cultural Ercilio Castillo que él mismo fundó en el año 2014, numerosas notas periodísticas así como objetos donados por los realizadores (moviolas, cámaras), cartas, correos electrónicos y, afortunadamente, películas. Los cortometrajes que nos interesan rescatar para este artículo son Cacique Catán (Castillo, 1975), Pinyo Olka (Castillo, 1975) y Campamentos juveniles (Castillo, 1973). En su película más reconocida, denominada Nosotros y Los Otros (Castillo, 1975), participó Jorge Ott en el diseño sonoro. Además Castillo es un activo defensor de la causa ambiental del Río Negro, bajo la cual ha filmado varios cortometrajes desde los 70 hasta la actualidad.

\footnotetext{
${ }^{18}$ Luego, en la época de la dictadura, Ott produjo un cortometraje sobre la refundación de la ciudad de Federación. Esta última película, llamada Federación, la ciudad itinerante (Ott, 1978), contó con la participación en el equipo de producción del arquitecto Ramón Gutiérrez, del cineasta Jorge Castillo, el iluminador Jacinto Reidán, René Cisneros y el hijo del director, Daniel Ott.

${ }^{19}$ Luego pasaría al video VHS profesional y posteriormente al digital.
} 
Passarelli. Los comienzos en la producción del cine documental chaqueño: cine científico y relaciones de alteridad...

Finalmente, el último de los realizadores chaqueños en el que me voy a detener es Isaac "Cacho" Belsky, oriundo de Las Breñas. Es ingeniero de profesión, pero a mediados de los años 70 filmó una serie de cinco películas relacionadas al mismo tema, la Fiesta del Inmigrante. Ellas son Caminante, no hay camino (Belsky, 1975), Capital del Inmigrante (Belsky, 1976), Seguir haciendo Chaco (Belsky, 1978), El breñal fue hace tiempo (Belsky, 1978) y Donde vive la esperanza (Belsky, 1980). Sus tres primeras películas son registros documentales sobre la fiesta, mientras que las otras dos mezclan el documental con la ficción. Luego Belsky trabajó en la UNNE, para en los 80 ingresar en Canal 9 de Resistencia. Dentro del canal, en el año 1985 produjo y condujo un programa de televisión que hoy, gracias a la conservación de Jorge Castillo, podemos ver algunos de sus capítulos. Se llamó Nuestro Cine, duró apenas dos meses y fueron aproximadamente 8 entrevistas a los pioneros del cine chaqueño, donde pasaron todos los realizadores que anteriormente mencionamos. Por lo tanto su registro y testimonio resultó clave para esta investigación. ${ }^{20}$

\section{El cine científico como herramienta educativa}

El cine, desde sus comienzos, ha sido utilizado desde el campo académico de dos modos diferentes: por un lado como instrumento de investigación científica destinado sólo a especialistas y por otro, como herramienta educativa para el público en general. El primero de ellos refiere a la capacidad de registro del dispositivo cinematográfico, la cual cristalizaba la observación científica como método, quedando filmados los datos para analizar en el laboratorio, el despacho del investigador o en las clases en las universidades. La botánica, la zoología, la medicina, la antropología, la arqueología y la astronomía son sólo algunas de las disciplinas que se han valido de cámaras y de técnicas del cine, como el plano detalle o las ampliaciones (las cuales ya se venían explorando desde la fotografía), para sus investigaciones. Dichas imágenes también, eran presentadas en los congresos científicos como materiales complementarios y "pruebas" del carácter verídico de la información.

Sin embargo, la que nos interesa desarrollar en el presente apartado es la segunda concepción, ya que muchas de las primeras películas chaqueñas tienen este propósito. Para el caso argentino, el cine científico como herramienta educativa tuvo su auge en las primeras décadas del siglo XX con numerosos films que en su mayoría se encuentran desaparecidos. Se proyectaban junto con actualidades, programas cómicos y grandes películas, y algunos, lograban tener un amplio éxito comercial. Así lo explica Andrea Cuarterolo,

La idea de un cine que instruye deleitando es fundamental

\footnotetext{
${ }^{20}$ Otro de los realizadores influyentes dentro del ámbito chaqueño de realización audiovisual fue José Luis "El Negro" Meana, quien "se reconoce discípulo de Fernández Pissano" (Castillo, 2003, p. 113). Dedicado más a la actividad televisiva en el Canal 9 de Resistencia, se destacan sus trabajos en equipo con el poeta Alfredo Veiravé como guionista, Ernesto Raúl Acosta en la locución y Raúl Cerrutti en la musicalización. Su producción, enfocada al cine de promoción y publicidad turística estatal, se extiende sobre la época de la dictadura y por lo tanto, no será abordada en el presente artículo.
} 
para comprender estas primeras películas científicas que, lejos de constituir un material accesible sólo para una elite de estudiantes y eruditos, se proyectaron con frecuencia en salas comerciales, se publicitaron y reseñaron en las revistas cinematográficas de la época y en ocasiones se convirtieron en verdaderos éxitos de taquilla (Cuarterolo, 2015, p. 54).

Estas películas tenían el propósito de poner en tensión los conocimientos habituales y el sentido común con los discursos de verdad construidos desde la lógica científica positivista. Se trataba de cuestionar las prácticas cotidianas, instruyendo al público a través de la narrativa cinematográfica. En este sentido combinaban espectáculo y educación, apuntando fundamentalmente a generar conciencia sobre enfermedades y sus formas de prevención. Cuarterolo (2015) destaca como pioneras en la Argentina La mosca y sus peligros (Martínez de la Pera y Gunche, 1920), La sifilis y sus consecuencias (Gallo, 1921) y La higiene en el matrimonio (Moglia Barth, 1928), ${ }^{21}$ correspondientes a la corriente higienista de principios del siglo XX. Siguiendo a la misma autora, estos cortometrajes intentaban amalgamar lo sensacional de las imágenes (por ejemplo en La mosca y sus peligros se recurre a representaciones terroríficas, asombrosas y cuasiteratológicas) junto con el saber académico de los procedimientos que se debían llevar a cabo para la detección y el análisis de la enfermedad. En este punto intermedio entre imágenes extraordinarias (que bordeaban lo fantástico) y la ciencia como discurso verdadero, el "ciudadano común" aprendía cómo debía actuar para poder prevenir las afecciones y así, lograr una "sociedad mejor".

Por consiguiente, estas películas se basaban en productos de investigaciones científicas y estaban respaldados por el asesoramiento de algún profesional de las mencionadas disciplinas. El investigador español León Bienvenido, señala dos características distintivas de los films de divulgación científica que se repiten en la cinematografía argentina y chaqueña,

1. Tratan sobre asuntos centrados en resultados de investigación, hechos o conocimientos relacionados directamente con alguna disciplina de la ciencia o argumentación basada en conocimientos científicos, incluyendo las ciencias naturales, aplicadas y sociales.

2. Muestran explícitamente (en la imagen, la narración o los títulos de crédito) que han contado con la colaboración o el aval de expertos o instituciones científicas, que han participado como fuentes de información o asesores de contenido (Bienvenido, 2008, p. 12).

El conocimiento académico aparecía en los intertítulos de los films silentes, dando cuenta de otra de las características distintivas. En las películas cronológicamente

\footnotetext{
${ }^{21}$ La primera todavía se conserva, mientras que las otras dos lamentablemente no.
} 
Passarelli. Los comienzos en la producción del cine documental chaqueño: cine científico y relaciones de alteridad...

posteriores y sonorizadas, va a existir la primacía del sonido sobre la imagen, a partir de la voz de un locutor, "donde el conocimiento estaba encarnado (desencarnado, diríamos mejor) tan sólo en la omnisapiente voz “de Dios” de la narración” (Ortega, 2002, p. 30). La voz over de un narrador marca el ritmo de las imágenes, indicando explícitamente al espectador lo que debe ver (y ocultando lo que no). Siguiendo a María Emilia Zarini (2016) en su análisis comparativo entre los films de divulgación científica de principios del siglo XX con los de la actualidad, la investigadora señala algunas características comunes con los autores que recién mencionábamos, como la voz omnisciente del narrador y la marca de autoridad por la presencia de científicos. A la vez, añade la utilización de ralenti o aceleración en la imagen como formas de atracción, el empleo de las cinemicrofotografías, las intervenciones gráficas (mapas, textos, datos, entre otras) y la animación. Por último, muchos de estos films son estructurados a partir de una "narrativa dramática", donde el personaje principal debe ir resolviendo problemas hasta lograr solucionarlos a partir del conocimiento científico (León, 2010, p. 6). Para complementar esta idea, agregamos que dicha narrativa responde a la organización de los eventos de una manera causal, donde espacio y tiempo están anclados a la verosimilitud, tienen un cierre narrativo y los personajes son psicológicamente cerrados (Bordwell, 1996).

Educación, ciencia y cine se entrelazan en los primeros films chaqueños, principalmente a partir del impulso de la Universidad Nacional del Nordeste $^{22} \mathrm{y}$, en parte, del Consejo Nacional de Investigaciones Científicas y Técnicas (CONICET). Sintetizando las ideas que recién se mencionaban, podemos enunciar algunos elementos comunes que encontramos entre los films que a continuación vamos a presentar. Uno de ellos es el uso de cinemicrofotografías o acercamientos de detalles con la utilización de teleobjetivos e intervenciones gráficas. Veremos cómo estas películas van a utilizar dicho recurso para atrapar al espectador (el cual ahora puede ver lo que antes le era imposible) y como prueba "irrefutable" de lo que narra la voz over. El uso de la capacidad de registro del dispositivo, aprovechando las nuevas posibilidades tecnológicas de la época, va a trasladar al público las microscópicas bacterias de la enfermedad de la lepra o los detalles del suelo desgastado por el monocultivo. La voz over como única guía del relato va a ser otra de las características fundamentales del cine chaqueño de divulgación científica, direccionando el curso y explicitando el pensamiento científico

\footnotetext{
${ }_{22}$ Durante los años 60 las universidades nacionales de Buenos Aires, La Plata, Córdoba y Santa Fe comenzaban a tener sus primeras escuelas de cine dedicando gran parte de sus intereses al cine de autor y al cine social. Sin embargo, las mismas universidades producían también materiales visuales y audiovisuales como complementación y ayuda de las cátedras, que ha sido poco estudiado dentro de la cinematografía argentina. El cine científico se establecía como un campo de creación fundamental y prolífica, que todas las instituciones educativas produjeron. Por ejemplo Robles y Balboa (2011) señalan una veintena de películas que el Instituto de Cine de la Universidad de Buenos Aires (creado en 1955) realizó, con temas de agronomía, veterinaria, geología, zoología, artes y etnografía, entre otras. La experiencia del caso de la Universidad Nacional de Tucumán es distinto porque la creación del Instituto Cinefotográfico (luego Instituto Cinematográfico de la Universidad Nacional de Tucumán -ICUNT-) data de 1937. Cabe destacar la producción dentro del ICUNT de la película Dramas del Rancho (1949), producida por el Instituto de Medicina Regional, donde se informaba a la población sobre la problemática del mal de Chagas.
} 
en la narración de un locutor. En este sentido, la construcción de un discurso de verdad es unívoca y se apoya en la intervención de médicos, científicos y laboratorios, sumado a los créditos de Institutos de Investigación o de la misma UNNE. El aval científico se torna como un elemento distintivo, especialmente al poner los cuerpos en pantalla, sus espacios y, en algunos casos, sus propias voces. Por último, la estructuración de los films a partir de una narrativa lineal con presentación del tema, conflicto y resolución (la cual sirve para la fácil interpretación del espectador) va a ser una constante sumado al tratamiento de temáticas locales relevantes para el contexto de la provincia (muchas veces asociadas con tabúes sociales) como la lepra o el mal de Chagas. El abordaje de problemáticas que han tenido un fuerte impacto en la provincia y en la región durante esos años, dan cuenta de una característica distintiva de estos films.

Podríamos catalogar como la primera experiencia dentro del cine local bajo este formato audiovisual a El camino de la verdad ${ }^{23}$ (Fernández Pissano, 1963), película que fue presentada más arriba a partir de su proceso de producción colectivo. El cortometraje aborda, desde una narrativa ficcional ${ }^{24}$ y lineal, la problemática de la lepra (o enfermedad de Hansen) contando la historia de un empleado quien trabaja en las oficinas de Aerolíneas Argentinas en la ciudad de Resistencia, el cual se ve contagiado al inicio del film y, en el final, logra curarse por el tratamiento médico. Con escenas documentales de las calles de Resistencia desde un plano general, una marcada altura de la cámara y un ángulo picado (Figura 1), comienza la película situando el relato en la mencionada ciudad. Vemos autos, personas y comercios de la capital chaqueña en constante movimiento, dando cuenta que el problema que se abordará en el film "le puede tocar a cualquiera" (sic del film). La voz over (que por momentos se transforma en off) de Juan Carlos Rousselot, reconocido locutor de la época, narra a lo largo de todo el film los acontecimientos que vamos viendo en pantalla y los que están por venir, los pensamientos y sentimientos del personaje (preocupaciones, tensiones, alegrías), los diálogos y las acciones. Toda la atención de la película pasa por el relato de Rousselot, quien monopoliza las interpretaciones y por lo general, se adelanta a los acontecimientos que le van a suceder al personaje. La película busca que el espectador empatice con el oficinista contagiado principalmente a partir del miedo que genera la enfermedad, a la vez que la voz del locutor firme y segura, nos da la solución al problema. Justamente el nombre del film El camino de la verdad se debe al temor por el desconocimiento del tratamiento (se creía que la lepra todavía no era curable)

\footnotetext{
${ }^{23}$ Digitalizada. Duración: 12:03. Soporte $16 \mathrm{~mm}$. Blanco y Negro. Créditos: Patronato de Leprosos (como se llamaba en esa época) y del Subdepartamento de la Lepra (Ministerio de Salud Pública del Chaco). Actuación: Alberto Carlos Celada, Mary Capponi, Claudio Domínguez y "personajes de la vida real" (sic). Colaboran: Cine S.E.P., Aerolíneas Argentinas- Agencia Resistencia, Biblioteca Lynch Arribálzaga, Escuela Nacional Benjamín Zorrilla, Diario El Territorio, LT 5 Radio Chaco, Pueblo de Resistencia. Locución: Juan Carlos Rousselot. Efectos especiales: Alberto Borfitz. Electricista: Alberto Medina. Asesor médico: Dr. Manuel Giménez. Productora: Chaco Gualamba. Libro, guión, fotografía, montaje: Ángel Fernández Pissano y Oscar Cerrutti. Dirección: Ángel Fernández Pissano.

${ }^{24} \mathrm{Si}$ bien la narrativa responde a estrategias de ficción principalmente, por momentos los límites con el documental se hacen difusos. En el análisis voy a ir marcando algunos de estos elementos que rompen las fronteras entre ambos discursos.
} 
Passarelli. Los comienzos en la producción del cine documental chaqueño: cine científico y relaciones de alteridad...

y al estigma que tenían los leprosos en la sociedad. ${ }^{25} \mathrm{El}$ tema elegido es particularmente significativo a lo local, ya que el "leprosario" (así se lo denominaba) de la Isla del Cerrito marcó un imaginario en la población resistenciana, dejando a la lepra como tema tabú. El camino de la verdad entonces, es el camino de la medicina. La ciencia aparece como la salida a la afección ya que se muestra cada paso del método médico para detectarla: desde el diagnóstico inicial, la punción sobre la mancha, el raspado en la dermis, la conservación de la muestra, los análisis microscópicos a través de microfotografías (Figura 2) y luego las recomendaciones del tratamiento. La imagen de confirmación que el paciente efectivamente ha contraído la enfermedad es la que exponemos en la Figura 2, donde con flechas blancas se señalan a los microbios vistos por el microscopio. El relato del locutor reafirma lo que vemos en pantalla, "finalmente el microscopio identifica los bacilos de Hansen que confirman y asegura el diagnóstico clínico”. En esta secuencia de imágenes, donde se exponen las máquinas y cada uno de los pasos que se siguen para el análisis, el registro de la película cambia al discurso documental, mientras que la voz over continúa con su relato. El oficinista, luego de superar el momento de recibir los resultados con notable tensión, realiza el tratamiento en unos meses y finalmente logra curarse.

Figura 1. Imágenes de la ciudad de Resistencia.

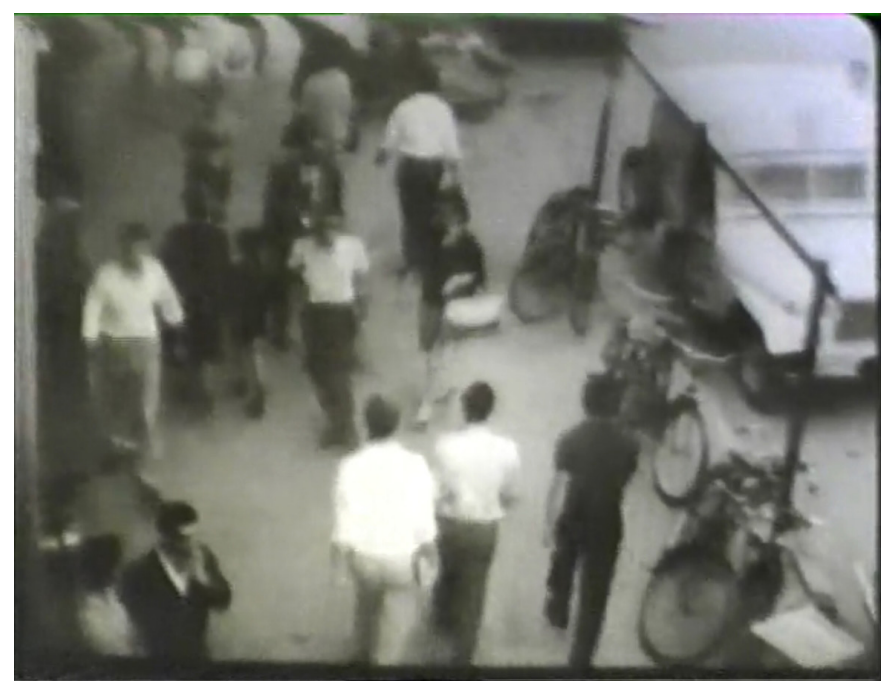

Fuente: Fotograma capturado de El Camino de la Verdad (Fernández Pissano, 1963)

\footnotetext{
${ }^{25}$ Hacia el año 1924 fue construida en la Isla del Cerrito (Chaco) una Colonia Regional de Leprosos, donde se recluían a aquellos que contraían la enfermedad. Los pacientes eran llevados a la Isla para realizar cuarentena y debían abandonar a sus familiares y sus objetos personales. Una vez dentro del centro de salud, eran alojados en pabellones y se les proveía de todo lo necesario para continuar con el tratamiento. Al no poder recibir visitas, rondaba un halo de misticismo alrededor de lo que les sucedía a los enfermos dentro de la Colonia. Además, algunos de ellos morían allí dentro y por lo tanto, la enfermedad de la lepra era asociado al miedo a dicho aislamiento que todavía circulaba en el imaginario de la población de Resistencia. Recordemos que durante los años cincuenta se descubrió el tratamiento vía oral para curar esta enfermedad y en los sesenta se suprimió la cuarentena como método preventivo, eliminando así, a los "leprosarios" de todo el país.
} 
Figura 2. Detección de la enfermedad a partir de las imágenes microscópicas.

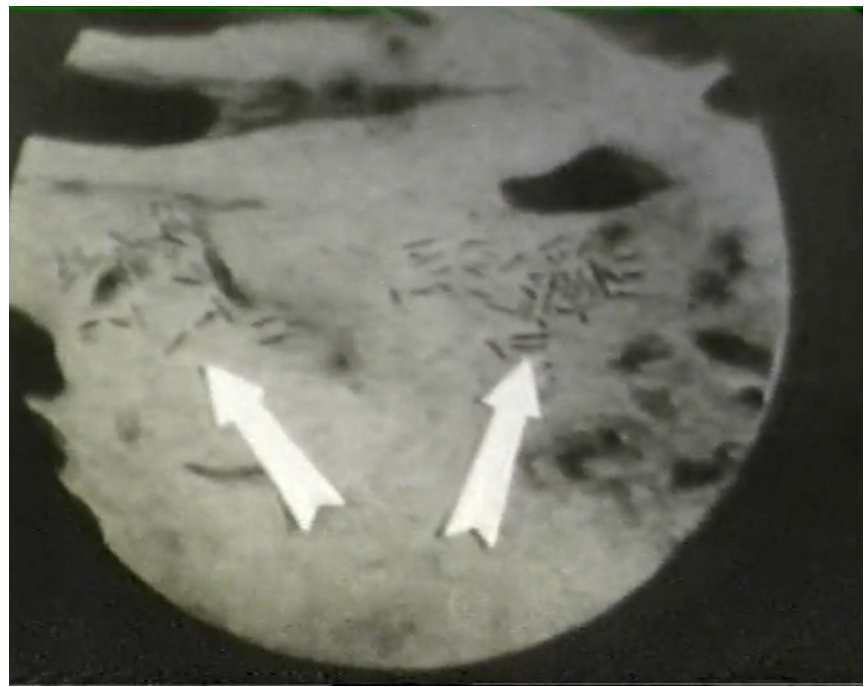

Fuente: Fotograma capturado de El Camino de la Verdad (Fernández Pissano, 1963)

El relato cambia en la mitad del film cuando el locutor dice, "Pero no todos los enfermos del Mal de Hansen proceden de la misma manera que el hombre de nuestra historia" y de este modo se presenta al Patronato de Leprosos. ${ }^{26}$ El film da cuenta del trabajo de concientización que hace esta asociación (a través de un mapa del Chaco -intervención gráfica-) y llegando al final se expone la enseñanza de la mencionada enfermedad en la escuela con registros documentales. La educación y la ciencia van de la mano en toda la narración, manteniendo su correlato en los contextos donde han circulado: escuelas, centros sociales y canales abiertos de televisión. Se trata entonces, de la divulgación del conocimiento científico, a partir del vínculo entre el espectáculo cinematográfico y la educación. A la vez, describe Ott que ha sido proyeccionista en reiteradas oportunidades de dicha película, sus exhibiciones eran acompañadas por médicos especialistas en la enfermedad para al final, intercambiar opiniones con los espectadores.

Con otra problemática totalmente distinta, pero bajo los mismos principios, resultaron una serie de films encargados por el Instituto Agrotécnico de la Facultad de Agronomía y Veterinaria (UNNE) en asociación con otras instituciones, con el fin de concientizar y enseñar a los productores agrícolas del interior chaqueño sobre la importancia de la rotación de cultivos. ${ }^{27}$ De todos ellos su director fue Juan Carlos Vidarte, quien por entonces estaba en el Departamento de Extensión Universitaria. El

${ }^{26}$ En la película el Patronato aparece constituido en su totalidad por mujeres, que son las que luego de tomar un curso de conocimiento sobre la lepra, inician el trabajo social yendo casa por casa a lo largo de toda la provincia del Chaco para informar sobre esta enfermedad.

${ }^{27}$ En este punto quisiéramos agradecer el apoyo del Instituto Agrotécnico de la UNNE y en especial, de su directora Ing. Agr. María Cándida Iglesias, quien nos ha facilitado gran parte del material fílmico con el que hemos trabajado. 
Passarelli. Los comienzos en la producción del cine documental chaqueño: cine científico y relaciones de alteridad...

mencionado director cuenta que la idea surgió porque se proyectaban a los productores locales pequeños films de campesinos estadounidenses, donde los chaqueños no se sentían identificados. Por lo tanto, estos nuevos cortometrajes creados en el Chaco, tenían la función de identificar a los espectadores a partir de la propia experiencia de reconocerse en pantalla. Resulta interesante cómo lo explica el propio Vidarte:
“[En las películas estadounidenses] Se veía a los productores subidos a modernos tractores, cuando ellos [los productores chaqueños] usaban el arado a disco; o atendían por teléfono a su mujer, desde el surco, cuando los llamaban a almorzar... todo muy idílico y extraño para sus vidas cotidianas" $(2006, \text { p. } 8)^{28}$.

Los cortometrajes eran proyectados en las mismas chacras, escuelas rurales y luego en la Universidad donde estaban apuntados al público en general. Los cortometrajes producidos por el Instituto Agrotécnico fueron Suelos de Monocultivo. Serie $1^{29}$ (Vidarte, 1962), Leguminosas. Serie $2^{30}$ (Vidarte, 1964), Recuperación de suelos salitrosos ${ }^{31}$ (Vidarte, 1965), Una revolución pacífica ${ }^{32}$ (Vidarte, 1965), Esteros y cañadas $^{33}$ (Vidarte, 1965), Inundaciones ${ }^{34}$ (Vidarte, 1966), Nitrógeno ${ }^{35}$ (Vidarte, 1970)

\footnotetext{
${ }^{28}$ El documentalismo que todavía nos UNNE (14 de septiembre de 2006). Norte, p.8.

${ }^{29}$ Digitalizada. Duración: 23:25. Soporte $16 \mathrm{~mm}$. Blanco y Negro. Créditos: Laboratorio de Investigaciones Agrícolas de la Fundación Juan Bautista Sauberán, Cátedra de Agricultura General FAV. de la UNBA y Consejo General de Educación de la Provincia del Chaco. Asesores Técnicos, Ingenieros Agrónomos: Jorge S. Molina, Pedro Fuentes Godo, Juan Quant Bermúdez, Gustavo A. Lundberg, Raúl Rios Reategui y Sres. Edwin Mac Donald y Guido Miranda. Montaje de sonido: Salvador Di Giuseppe, Grabación de sonido: Angel García, Proyección: Jacinto Reidan, Coordinador General: Raúl Rodríguez, Diagramación: Marcos Otaño, Locución: Victor Mercado. Asesora literaria: Rosi B. T. de Vidarte. Jefe de producción: Erlinda M. Z. de Duran. Montaje y Dirección: Juan Carlos Vidarte.

${ }^{30}$ Digitalizada. Duración: 11:30. Soporte $16 \mathrm{~mm}$. Blanco y Negro. Créditos: Producción de la UNNE. Asesores Técnicos, Ingenieros Agrónomos: Jorge S. Molina, Pedro Fuentes Godo, Juan Quant Bermúdez, Santos Soriano, Gustavo A. Lundberg y Edwin Mac Donald. Grabación de sonido Salvador Di Giuseppe, Proyección: Jacinto Reidan, Coordinador General: Jorge Vidarte, Diagramación: Marcos Otaño, Locución: Adolfo Becker. Guión: Guido Miranda. Colaboración literaria: Rosi B. T. de Vidarte Proyección: Antonio Álvarez. Jefe de producción: Erlinda M. Z. de Duran. Idioma: Original en español, traducida al guaraní. Montaje y Dirección: Juan Carlos Vidarte.
}

${ }^{31}$ Digitalizada. Duración: 11:29. Soporte: 16 y 35 mm. Color. Créditos: Cátedra de Agricultura General FAV de la UNBA y Instituto Agrotécnico de la F.A.yV. de la UNNE. Asesores Técnicos, Ingenieros Agrónomos: Carlos Sauberan, Jorge S. Molina, Pedro Fuentes Godo, Gustavo A. Lundberg. Música: Federico Pisarello, Grabación: Salvador Di Giuseppe, Proyección: Alberto Medina, Coordinador General: Jorge Vidarte, Diagramación: Marcos Otaño, Locución: Francisco A. Ayala. Guión: Rosi B. T. de Vidarte. Montaje: Raúl Dell'Oro. Idioma: Original en español, traducida al guaraní. Dirección: Juan Carlos Vidarte (La versión a la que pudimos acceder es la traducida al guaraní).

${ }^{32}$ Film perdido, sin datos.

${ }^{33}$ Film perdido. Filmado en $35 \mathrm{~mm}$, a color. Fue una coproducción UBA- UNNE con fondos del CONICET. Idioma: Original en español, traducida al guaraní.

${ }^{34}$ Film perdido, sin datos.

${ }^{35}$ Digitalizada. Duración: 10:26. Soporte: $16 \mathrm{~mm}$. Color. Créditos: Departamento de Extensión Universitaria y Ampliación de Estudios (UNNE) e Instituto Agrotécnico de la F.A.yV. de la UNNE. Asesores Técnicos, Ingenieros Agrónomos: Juan Quant Bermúdez, Pedro Fuentes Godo, Edwin Mac Donald, Amilcar Aguirre, Anselmo Casteny, Eduardo Silvestrini. Música: Crescencio Lescano y su grupo los chaqueñitos. 
y La Escuela, medio conservacionista (Vidarte, aprox. 1970). La estructura narrativa de todos los films es la misma. En un principio se menciona al suelo fértil producido la materia orgánica del monte como una historia pasada, luego se describe la explotación por el monocultivo y al final, se expone la solución a este problema por la rotación de los mismos. Sin información gráfica pero cargado de datos estadísticos con la voz over, las imágenes van desde paneos con planos generales de los campos algodoneros hasta detalles del suelo al máximo nivel posible. A continuación nos vamos a detener en el análisis de uno de los films, dado que se distingue del resto por la incorporación de la problemática social al argumento.

La temática principal de Suelos de Monocultivo. Serie 1 (Vidarte, 1962), aborda el desgaste y agotamiento del suelo a partir del monocultivo algodonero. ${ }^{36} \mathrm{En}$ esta película el aval científico aparece en los créditos al inicio y en la voz over. Al comienzo del film, se menciona el nombre de todos los asesores técnicos e ingenieros agrónomos que participaron de la producción (ver nota al pie No. 29) y, a su vez, aparece el intertítulo "El tema del film se ha realizado tomando como base los trabajos de investigación efectuados por: Instituto Agrotécnico de la FAV de la UNNE y Asociación Amigos del Suelo"37, marcando que el cortometraje es el resultado de una pesquisa científica. La voz over del locutor Víctor Miguel Mercado ${ }^{38}$, relata en un tono constante información respectiva a cómo incide la explotación agrícola sin rotación. Son datos estadísticos sobre la economía rural chaqueña, donde la fundamentación científica se apoya en las matemáticas y con estos datos, las imágenes van a ir complementando el discurso del narrador. En un comienzo el locutor nos cuenta, que el suelo chaqueño fue muy fértil por la acumulación de material orgánico a lo largo de años y esto trajo importantes beneficios para los productores, y por ende, para la economía chaqueña. Los planos son generales y con paneos suaves de campos algodoneros, hasta que la cámara baja su angulación y se detiene en una porción de tierra desde un primer plano, donde las manos excavan en la tierra arcillosa (Figura 3). La misma está reseca, agotada y tosca. El primer plano de la tierra, en este caso, funciona como prueba indiscutible de lo que el narrador nos cuenta. "La pérdida progresiva de materia orgánica ha hecho que estos suelos fueran perdiendo su porosidad original y junto con ella, por acción de la lluvia, la capa de suelo fértil" 39 . La imagen refuerza a la perfección el relato,

Grabación: Salvador Di Giuseppe. Locución: Francisco A. Ayala. Guión: Rosi B. T. de Vidarte. Montaje: Raúl Dell'Oro. Dirección: Juan Carlos Vidarte.

${ }^{36}$ Para contextualizar la importancia del tema del monocultivo algodonero cabe señalar que el Territorio Nacional de Chaco había tenido durante la primera mitad del siglo XX un fuerte impulso económico a través de la extracción primero del quebracho (la implantación de empresas multinacionales con este fin) y luego, el cultivo de algodón. Esto generó una creciente burguesía local "constituyendo al colectivo de los productores chaqueños en la fracción hegemónica del territorio chaqueño" (Roze, 2005:7). La situación económica durante el periodo que analizamos en este artículo, cambió rotundamente el rumbo que venía de años anteriores. La provincia del Chaco, durante los primeros años de los 60 , comenzó una profunda crisis económica debido a la baja del precio del algodón por el reemplazo de la fibra artificial.

${ }^{37}$ Universidad Nacional del Nordeste (productora) y Vidarte, J. C. (director). (1962) Suelos de monocultivo. Serie 1. País: Argentina.

${ }^{38}$ Locutor de la vieja LT5 Radio Chaco, fue poeta e integrante del Coro Polifónico de Resistencia.

${ }^{39}$ Universidad Nacional del Nordeste (productora) y Vidarte, J. C. (director). (1962) Suelos de monocultivo. 
Passarelli. Los comienzos en la producción del cine documental chaqueño: cine científico y relaciones de alteridad...

sosteniéndolo con sus propiedades técnicas, como es el encuadre desde un primer plano. El argumento del cortometraje es que con la implantación del monocultivo y la quema del rastrojo, ese suelo que antes era provechoso ha perdido su rendimiento. Como consecuencia, el sustrato va desintegrando de a poco su estructura y fertilidad natural, exigiendo al productor invertir en maquinaria más potente para la labranza. Si bien no hay placas gráficas con números, el texto del locutor nos cuenta los miles de kilogramos de algodón que se cosechaban por hectárea hace unos años atrás y los pocos que se juntan ahora (en referencia al año 1962). Como parte del problema social que esto genera, el narrador afirma que el agua no filtra por estos suelos y corre hacia las cañadas, arroyos y ríos aumentando su caudal, provocando inundaciones de poblados rurales y urbanos. Se muestran aquí, imágenes dramáticas de casas sumergidas (Figura 4), con paneos generales que recorren la inundación desde el agua. "Junto con el suelo se va el Hombre, la erosión humana", describe el locutor, mientras que vemos casas abandonadas, representando los problemas sociales que trae el monocultivo, como la pobreza y la migración. La voz de Mercante sigue relatando que las familias migrantes de las colonias agrícolas tienen como destino los grandes centros urbanos y, al no encontrar trabajo, forman en la periferia las "villas miserias" (sic del film). Imágenes de niños y ancianos en casas de condiciones precarias, acompañan el relato. La solución a esta cadena de problemas agrícolas y sociales, es la reconstrucción de los suelos a partir la rotación de los cultivos con alfalfa y gramíneas, así como el aprovechamiento del rastrojo del algodón utilizándolo como abono. El relato se apoya en las cifras que menciona el locutor, dando cuenta del porcentaje de ahorro que el productor podría alcanzar y cuánto más lograría llegar a producir realizando este método. Con un final en tono heroico, la música aumenta su pulso, la cámara se vuelve más vertiginosa dando cuenta de la acción de lo nuevo y de lo que está por venir. Con la imagen de un amanecer, el film finaliza afirmando que la otorgación de créditos para estos fines de rotación es el "Único camino hacia una agricultura estable y productiva, para dar al Chaco algodonero el deseo que vislumbraban los esforzados colonos friulanos para ejemplo del país y el mundo entero". ${ }^{40}$

Serie 1. País: Argentina.

${ }^{40} \mathrm{Si}$ bien la película visibiliza el problema social que produce el monocultivo de algodón, oculta sin embargo los conflictos que ocasiona el desmonte y la explotación de los trabajadores en el campo. Esta invisibilización del desmonte cambia en la época del golpe militar de 1976, transformándose en eje de la narración. Particularmente, las ideas de progreso y desarrollo estaban ancladas al avance sobre el "desierto verde", quedando en evidencia en películas del mismo director como La Conquista del Oeste (Vidarte, 1978). 
Figura 3. Primer plano de las manos.

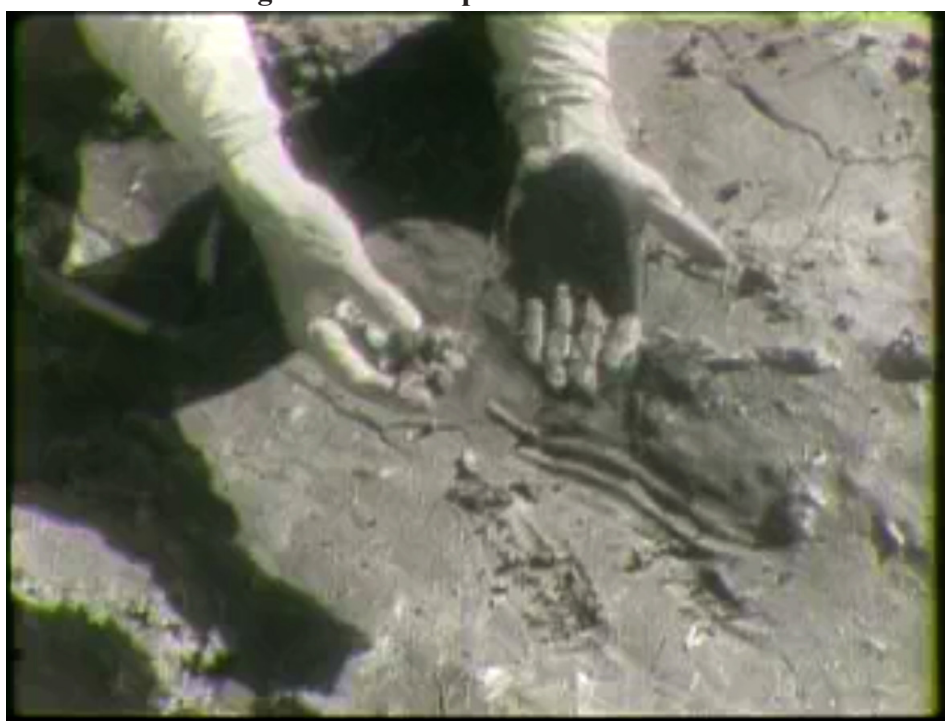

Fuente: Fotograma capturado de Suelos de Monocultivo. Serie 1 (Vidarte, 1962)

Figura 4. Paneo sobre las casas sumergidas.

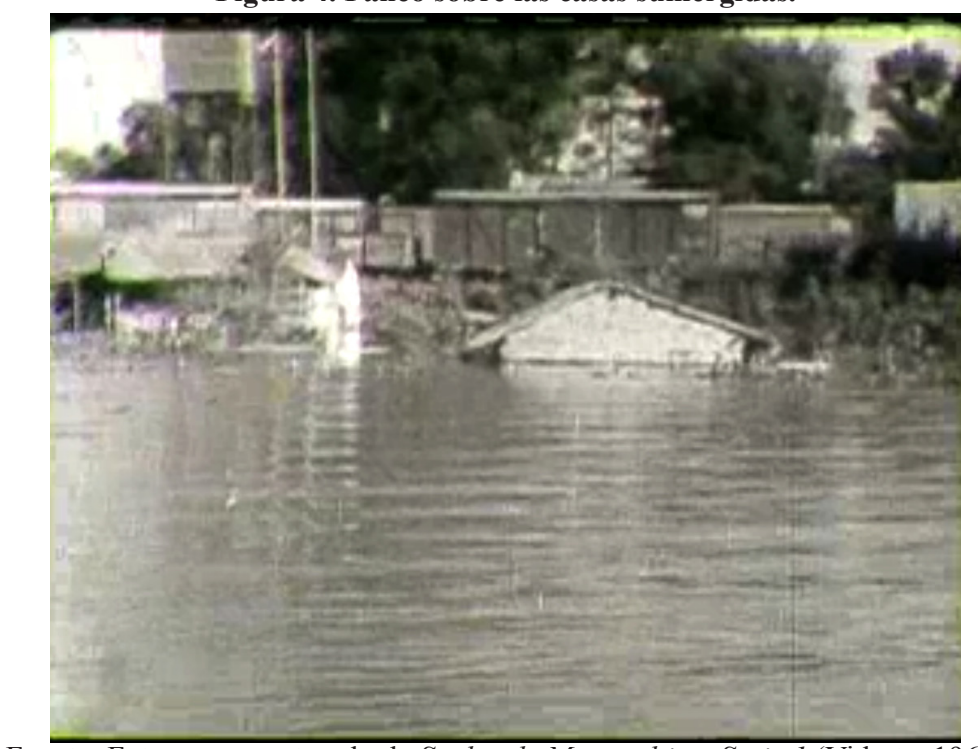

Fuente: Fotograma capturado de Suelos de Monocultivo. Serie 1 (Vidarte, 1962)

Siguiendo con la línea de películas científicas educativas, la UNNE, a través de sus diferentes institutos y facultades, promovió una serie de audiovisuales respectivos a la detección de la enfermedad de Chagas. El Instituto de Medicina Regional (UNNE), bajo la dirección del Dr. Jorge Yanovsky, encomendó a Jorge Ott el cortometraje (hoy perdido), Vivir puede ser hermoso (1975). Principalmente destinado a los enfermeros 
Passarelli. Los comienzos en la producción del cine documental chaqueño: cine científico y relaciones de alteridad...

y a los encargados de los centros de salud (que no eran médicos) de otros puntos del Chaco, se explicaba el mecanismo de serología en el laboratorio, el cual determinaba si el paciente tenía o no la enfermedad. El camarógrafo fue “Cacho” Belsky y el cortometraje, duraba aproximadamente 20 minutos. Siguiendo el modo de representación propio del documental expositivo, Belsky asegura que era una película didáctica donde el relato de la voz over lo hizo el propio Yanovsky y el armado de la película la realizaron en la casa de Jorge Ott. Otro de los cortometrajes producidos por la UNNE en este momento y que continúan perdidos, fue Docencia e investigación en el complejo técnico social (Ott, 1975 ) fomentado por la Facultad de Medicina (UNNE) y otras instituciones. El film abordaba los mecanismos del autoanalyzer como detector de la enfermedad de Chagas.

\section{Cine de la diferencia}

Dentro del presente apartado nos detenemos en cortometrajes que reúnen distintas temáticas como la artesanía indígena, los carnavales, la fiesta del inmigrante, la religiosidad popular y la migración. Los recopilamos bajo el nombre de "cine de la diferencia" ya que en función del provincialismo y regionalismo que marcábamos en la introducción del artículo, muchas de estas películas intentaban abordar los contornos de la "identidad chaqueña" a partir de problemáticas culturales y sociales. La categoría central del análisis va a ser la construcción de las relaciones de alteridad, partiendo del fundamento inicial que toda representación audiovisual de la(s) cultura(s) implica necesariamente un encuentro. Cámara, realizador y sujeto filmado (antiguamente el "Otro cultural") se entrecruzan en un sinfín de relaciones en múltiples niveles. Como decíamos en la introducción del artículo, los tres agentes están inmersos en un mismo contexto social, histórico, político y cultural, en el cual las relaciones de poder, los cursos históricos sobre la producción de realidad y los discursos, quedan condensados en el proceso de producción, en la representación y en la circulación del audiovisual. Por lo tanto, el mecanismo específico del cine de la diferencia, va a ser el constante juego entre las relaciones de reconocimiento o distanciamiento ${ }^{41}$ del realizador y el sujeto filmado, mediados por la cámara y cruzados por el contexto.

Como herramientas de análisis vamos a emplear el punto de vista narrativo y su tratamiento sonoro (voz), para dar cuenta de estas relaciones de acercamiento o lejanía. Nos centramos en el análisis de la representación, donde exponemos las formas fílmicas ${ }^{42}$ empleadas por los realizadores. Así es que nos focalizamos en el uso de las cualidades específicas del lenguaje audiovisual, las cuales nos dirigen a pensar en determinadas significaciones/emociones (Metz 2002 [1967]). Se trata de analizar la construcción del punto de vista y del empleo de la voz over, para dar cuenta de cómo son representados los sujetos. Con el término punto de vista, a partir de la teoría del cine, nos referimos a:

\footnotetext{
${ }^{41}$ No queremos con esto cerrar la definición de alteridad a una división dicotómica entre reconocimiento y distanciamiento. En las películas que voy a analizar a continuación, voy a plantear cómo dentro de estas dos operatorias sociales, hay diversas variantes y puntos intermedios entre una y la otra.

${ }^{42}$ Entendiendo la relación forma/contenido como dialéctica, donde se hacen indistinguibles los límites entre uno y otro.
} 


\begin{abstract}
"Un emplazamiento, real o imaginario, desde el cual se produce una representación. Es un punto en el cual un pintor que utiliza la perspectiva lineal organiza su cuadro; y también, en el cine, el punto imaginario, eventualmente móvil implícito en cada plano" (Aumont y Marie, 2006, p. 183-184).
\end{abstract}

Este término refiere a la configuración de las herramientas del lenguaje audiovisual que emplea el realizador y los sentidos que dicho sistema genera. De este modo, se pone de manifiesto desde dónde mira y enuncia el realizador a partir del encuadre y el montaje, dando cuenta de las relaciones entre ellos. Sumado a esto, vamos a analizar la utilización del sonido centrándonos en el empleo de la voz over. Quiénes son los que hablan y de qué modo lo hacen, va a ser una premisa que guiará el análisis. A partir de la combinación de estos elementos vamos a intentar distinguir las mencionadas relaciones de alteridad dentro de las representaciones.

En el contexto argentino, las representaciones sobre la cultura y la alteridad han tenido una profundidad tan grande como la historia misma del cine. Podemos tomar como punto de partida el film El Último Malón (Greca, 1917), el cual podría ser considerado por su tema, por su configuración espacio-temporal y fundamentalmente por sus condiciones de producción, como una obra pionera del cine regional (Kohen, 2009). Otras producciones de principios del siglo XX son Terra Magellaniche filmada entre 1915 y 1933 por Alberto María de Agostini y las obras de exploradores y viajeros en $\operatorname{los} 20$ y 30, descriptas por Andrea Cuarterolo (2013) y Mariana Giordano y Anne Gustavsson (2013). Estos primeros relatos audiovisuales etnográficos (aunque ninguno de ellos era antropólogo) se constituían como un valioso tesoro de "rasgos culturales" que estaban en peligro de "extinción". Explotando la idea de imagen como registro, las culturas amenazadas por el avance de la sociedad occidental podían quedar "congeladas en el tiempo" en el interior del material fílmico. Dicho tipo de construcción representacional no manifestaba la diferencia del sistema visual entre unos y otros, sólo tenían "voz" aquellos que filmaban, no incorporaban el conflicto social ni las relaciones de poder en el cuerpo del relato y descontextualizaban a los sujetos remontándolos a un pasado por fuera de la historia. La relación entre realizador y sujeto filmado estaba quebrada por la alteridad y unida por la cámara.

El aprovechamiento de las cualidades descriptivas del cine por parte de las ciencias antropológicas dio origen a numerosos films documentales-etnográficos, cuya principal función fue (y aún sigue siendo) la de conservar un registro de usos y costumbres de pueblos en vías de cambio y/o desaparición (Guarini, 1985, p. 149).

Como vamos a describir en el presente apartado, durante la época de los $60 \mathrm{y}$ 70 , en las representaciones audiovisuales sobre los indígenas chaqueños muchos de estos presupuestos continuaban. De forma complementaria, veremos cómo en el mismo proceso de construcción de la alteridad por la diferencia, también aparecía el reconocimiento 
Passarelli. Los comienzos en la producción del cine documental chaqueño: cine científico y relaciones de alteridad...

de ciertos sujetos, prácticas y lugares. La mirada de los realizadores muchas veces se identificaba en los representados, como por ejemplo los campesinos, los estudiantes y los inmigrantes. A la vez, los lugares urbanos y rurales, son escenarios conocidos y cotidianos, donde la cámara se desenvuelve con seguridad. Las imágenes se presentaban como un "reflejo nítido de la realidad", por primera vez creado por ellos mismos.

Cosecheros (1955) es el primer film de Juan Carlos Vidarte. Según los diálogos relatados en un correo electrónico de Jorge Castillo con el realizador, la historia fue filmada en el puerto de Barranqueras y en la estación de tren, narrando la espera de los cosecheros para viajar a los diferentes destinos laborales de la provincia y el país. En este film, que entrecruza discursos de ficción y documental, actuaron los reconocidos artistas locales Poen Alarcón y Aída Bertoni. Luego, junto con las producciones de cine científico que describimos en el anterior apartado, encontramos Operativo titus (1967) y Carnaval para vivir (1969). Las dos películas, de temáticas bien distintas, no han podido ser reconstruidas porque en la actualidad se encuentran perdidas y no hay fuentes secundarias que indiquen información.

1972 es una fecha clave para entender el quiebre en el cine documental chaqueño, a partir del estreno de dos cortometrajes: Oscar Medina, artesano ${ }^{43}$ (Vidarte, 1972) y En Busca de San La Muerte (Ott y Molina y Vedia, 1972). La primera película se divide en dos grandes partes. En la primera narra la actividad alfarera de Oscar Medina, perteneciente a la comunidad Qom (en la película nombrado como "Toba"), que vive en Villa Sarmiento, un barrio en las afueras de Resistencia. En el segundo segmento del film la narrativa cambia y la película se centra en el Centro Experimental de Promoción Artesanal (CEPA -perteneciente a la Secretaría de Extensión de la UNNE-44) y en las actividades que allí se realizan. La película sigue la estructura cronológica de un día, desde que el personaje se levanta cuando sale el sol, lava su cara, busca la arcilla y la moldea, hasta la tarde, cuando almuerza con su familia, duerme la siesta y asiste al CEPA. De este modo, siguiendo la lógica de las películas científicas que describíamos en el anterior apartado, ${ }^{45}$ a lo largo de todo el film escuchamos el relato del locutor, quien nos marca cada uno de los pasos que el artesano sigue para realizar la cerámica. Mientras vemos en pantalla al personaje principal armar un fuego, tomar mate y luego salir con su familia a buscar agua, el locutor narra:

"Como todos los días, la jornada de Oscar Medina se inicia con el mate mañanero. Al igual que la mayoría de los

\footnotetext{
${ }^{43}$ Digitalizada. Duración: 15:10. Soporte $16 \mathrm{~mm}$. Color. Formato: Fílmico. Dirección: Juan Carlos Vidarte. Asesor Técnico: Raúl Cerrutti. Cámara: Juan Carlos Vidarte y Elsa Chapotot. Locución: Adolfo René Becker. Sonido: Eduardo Bértola. Compaginación: Raúl Dell'Oro. Premios: Segundo Premio en el Quinto Festival de Cine Arte, producido por el Fondo Nacional de las Artes.

${ }^{44}$ Sorprende el relato de Vidarte, quien aclara en una entrevista realizada en el año 85 por "Cacho" Belsky en el programa "Nuestro Cine", que el trabajo fue financiado por ellos mismos, sin ayuda de la UNNE. Sin embargo en la placa inicial se indica la pertenencia a esta institución.

${ }^{45}$ Se mantienen las recurrencias de la primacía de la voz over, la construcción de un discurso de verdad, el uso de la capacidad de registro del dispositivo y la narrativa lineal. Sin embargo no aparecen científicos ni especialistas en el tema, pero sí instituciones educativas, como la UNNE.
} 
aborígenes chaqueños Oscar está integrado al pueblo criollo, aunque conserva el idioma de sus mayores y mantiene la herencia cultural de algunas tradiciones que poco a poco se van diluyendo, con la adopción de la cultura civilizada"46.

Cuando regresan a la casa y Oscar Medina comienza a elaborar las artesanías, el encuadre se mantiene con acercamientos al rostro y, principalmente, a las manos del personaje principal. El punto de vista de la enunciación se sitúa en reconocer y aprender cada uno de los pasos de la técnica de fabricación, a partir de los primeros planos, aprovechando las cualidades de registro del dispositivo. La secuencia construye, desde la perspectiva del realizador, una fórmula o receta para la elaboración de cerámica indígena. La segunda parte del cortometraje modifica la dimensión del relato, al describir las actividades que se realizan en el CEPA. Allí vemos vecinos y lugareños, indígenas y criollos, trabajando con artesanías en madera, arcilla y mimbre mientras se relatan las posibilidades que brinda el Centro, las cuales tienen un alcance regional. Lo que se explica en la siguiente frase:

"Al igual que indígenas y criollos de las provincias de Corrientes, Misiones y Formosa, en cuyos territorios funcionan talleres del CEPA similares al de Villa Sarmiento, los Medina aprenden y realizan trabajos artesanales que constituyen un tesoro cultural de la región y una expresión genuina del arte popular tradicional que debe ser preservado, desarrollado y difundido con generosa dimensión". ${ }^{47}$

En esta instancia, vemos cómo el film integra a los indígenas con las estructuras estatales, siempre siguiendo a la artesanía como eje de la cultura.

Figura 5. Detalle de Oscar Medina recortando la arcilla.

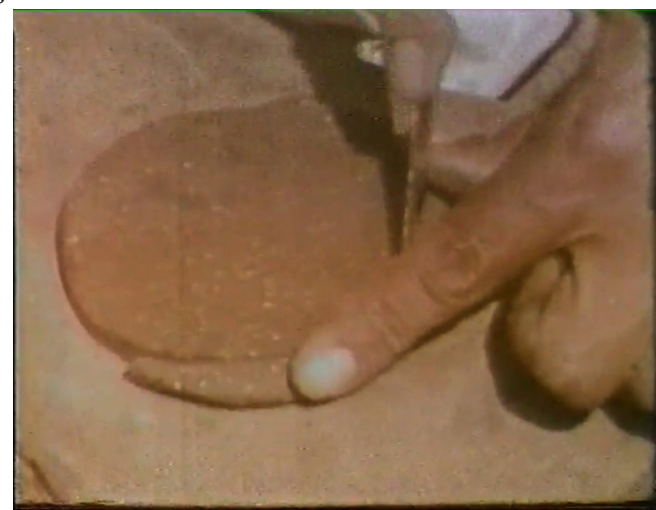

Fuente: Fotograma capturado de Oscar Medina, artesano (Vidarte, 1972)

\footnotetext{
${ }^{46}$ Universidad Nacional del Nordeste (productora) y Vidarte, J. C. (director). (1972) Oscar Medina, artesano. País: Argentina.

${ }^{47}$ Universidad Nacional del Nordeste (productora) y Vidarte, J. C. (director). (1972) Oscar Medina, artesano. País: Argentina.
} 
Figura 6. Rostro de Oscar Medina.

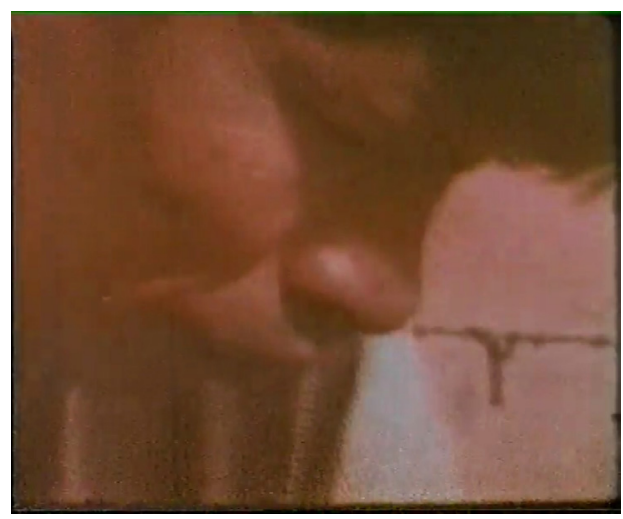

Fuente: Fotograma capturado de Oscar Medina, artesano (Vidarte, 1972)

El texto del relato sitúa al film en las discusiones del momento sobre el rol del indígena en la sociedad, entre la integración y la diversidad, el presente y el pasado, la herencia cultural y la transformación. La película se plantea entonces como un ejercicio de "salvataje cultural", donde se intenta registrar aquello que se está por perder constituido como "la sabiduría de los antepasados" (sic del film). En este sentido, el locutor habla de forma unívoca y directa describiendo cada una de las acciones del personaje principal, con una constante referencia al tiempo pretérito. Con esto, ubica a los indígenas fuera del contexto social y político de Resistencia de los setenta, desplazándolos más allá de la historia. Las ideas "culturalistas", intentando entender a la cultura en sus "propios términos", catalogando y clasificando a los diferentes grupos a partir de su lengua, sus producciones materiales y sus cosmogonías, se cruzaba con el proceso de "taxidermización" (Rony, 1996) del indígena "bueno", quien iba a perder lo pintoresco de su cultura. La artesanía se convertía en el medio de retrato ideal para este propósito, como observamos en la película. En síntesis, la alteridad está marcada por la diferencia donde la autoridad y el poder siempre están del lado de los que tienen la cámara, y la fuerza del "Otro", aparece negada en la representación.

Como sostiene el antropólogo argentino Hugo Ratier "el "otro cultural" sigue siendo "absolutamente otro, testimonio, objeto, materia prima de una manipulación a la que permanece ajeno, al margen de americanismos o humanismos retóricos" (2010, p. 29). En un doble juego entre la construcción de una identidad cultural y un "humanismo retórico" disuelto, es significativa la última frase del locutor, en tono heroico, afirmando:

“Oscar Medina argentino, chaqueño, indígena y esencialmente ser Humano ha encontrado un camino de fe y esperanza que le ayuda a vislumbrar un futuro de optimismo donde la felicidad de su vida realizada le permita la satisfacción de decir con orgullo ante una sociedad que lo comprenda y lo respete, soy 


\section{Oscar Medina, artesano”. ${ }^{48}$}

Sintetizando estas ideas, la película responde a los presupuestos del esquema reparacionista- reivindicatorio, que describe la historiadora Mariana Giordano,

Por consiguiente, el respeto a su cultura se daba más específicamente en el campo de las nominaciones y no de las acciones: se exclamaba su reconocimiento y difusión, pero a la vez se veía necesaria la aculturación que llevara a asegurarles los "beneficios del progreso", presupuestos del esquema civilizatorio de un siglo atrás (Giordano, 2004, p. 267).

La segunda película estrenada en 1972 es En busca de San La Muerte codirigida por Jorge Omar Ott y Mario Molina y Vedia. Bajo la influencia de las ideas de los fundamentales documentalistas Jorge Prelorán y Fernando Birri, la película pretendía "documentar la realidad social" estrategias de ficción y documental ${ }^{50}$ siguiendo la historia de Cándida Gómez, quien espera la vuelta de su marido de Buenos Aires, el cual había migrado unos meses antes en busca de trabajo. Oriunda de Margarita Belén, vive sola con sus tres hijos y decide trasladarse a Resistencia para conseguir empleo en el lavado de ropa. Allí ocupa una casa precaria y debido a las condiciones de pobreza que atraviesan, su hija Juana se enferma. Para resolver estos problemas la protagonista busca respuestas en San La Muerte, santo pagano de culto popular regional. La película sigue el recorrido de Cándida desde los consejos de vecinos y amigos hasta la compra de la pequeña escultura del santo en la cárcel y su veneración, festejo y peregrinación en diferentes ciudades de Chaco y Corrientes. Si bien la película se centra en la religiosidad popular como tema principal, se destaca por el cruce con problemas sociales que envuelven la devoción. Aparecen de este modo la explotación tabacalera y algodonera, la falta de empleo, la migración, la violencia policial y el acceso a la educación y la vivienda. Se presenta el culto a San La Muerte no como una actividad aislada, fija e inmóvil, sino anclada a un contexto social particular y rodeada de concepciones colectivas que nutren en capas de complejidad al film. El desplazamiento permanente del personaje, transitando por la ruta desde Margarita Belén a Resistencia, o desde Resistencia a Corrientes por los "vaporcitos", o desde la cárcel a las iglesias, sitúan al personaje en un tiempo presente, desafiando la mirada romántica y esencialista que veíamos en el film anterior. La mirada de los realizadores reconoce esos espacios, se desplaza en ellos y actúa de forma cotidiana.

\footnotetext{
${ }^{48}$ Universidad Nacional del Nordeste (productora) y Vidarte, J. C. (director). (1972) Oscar Medina, artesano. País: Argentina. Como parte de ese mismo "humanismo retórico" que señala Ratier (2010), Vidarte se sorprende cuando le realizan una entrevista en el año 1985 (trece años después del estreno) y sigue manteniendo las mismas ideas. En el programa de Cacho Belsky, afirma que con esta película "Me di cuenta que el aborigen nuestro tiene los mismos sentimientos que tengo yo con mi familia".

${ }^{49}$ Entrevista personal a J. O. Ott, 30 de Mayo de 2019.

${ }^{50}$ La película emplea imágenes mayormente ficcionales, donde la protagonista del film es Aída Bertoni, pero incorpora registros documentales en la construcción de las situaciones. Con el sonido ocurre lo inverso, son pequeños fragmentos de entrevistas en función de la narrativa ficcional.
} 
Passarelli. Los comienzos en la producción del cine documental chaqueño: cine científico y relaciones de alteridad...

Ese "Otro" que antes era sujetado por sus propias prácticas "culturales" a un tiempo pasado, sin relevancia de cambio en el presente, ahora se constituye como "Otro" social y político.

El elemento clave para este cambio de perspectiva es la construcción del punto de vista de los personajes a partir de la exploración sensible del lenguaje audiovisual y la incorporación de las voces de los creyentes. El lugar de enunciación del realizador intenta situarse en el punto de vista del personaje. Cándida Gómez mira, escucha, sueña, imagina, sufre, festeja y piensa. A lo largo de muchas escenas la película intenta situarse sobre cómo la protagonista ve y escucha el mundo a través de acortar la distancia entre la cámara y la protagonista. Por ejemplo cuando Cándida sale de la cárcel luego de comprar su pequeña escultura de San La Muerte, pasea por una feria donde venden diferentes tipos de colgantes religiosos. El personaje deambula entre los negocios, mirando los objetos de cruces cristianas mezcladas con imágenes de santos paganos. El encuadre pasa desde un paneo general como presentación del espacio, a un seguimiento con planos generales más cortos, en el que se la ve caminar y mirar fuera de campo. Luego el cuadro se acerca a ella desde un primer plano por detrás (Figura 7), para después ir a los detalles de los objetos (Figura 8). El sonido está articulado por la música, el murmullo de la gente y el relato de un hombre que cuenta sobre los poderes del santo. Esta pequeña escena, da cuenta de cómo Cándida atravesaba el mundo y cómo ese mismo mundo, la atravesaba a ella.

Figura 7. Construcción del punto de vista de Cándida López.

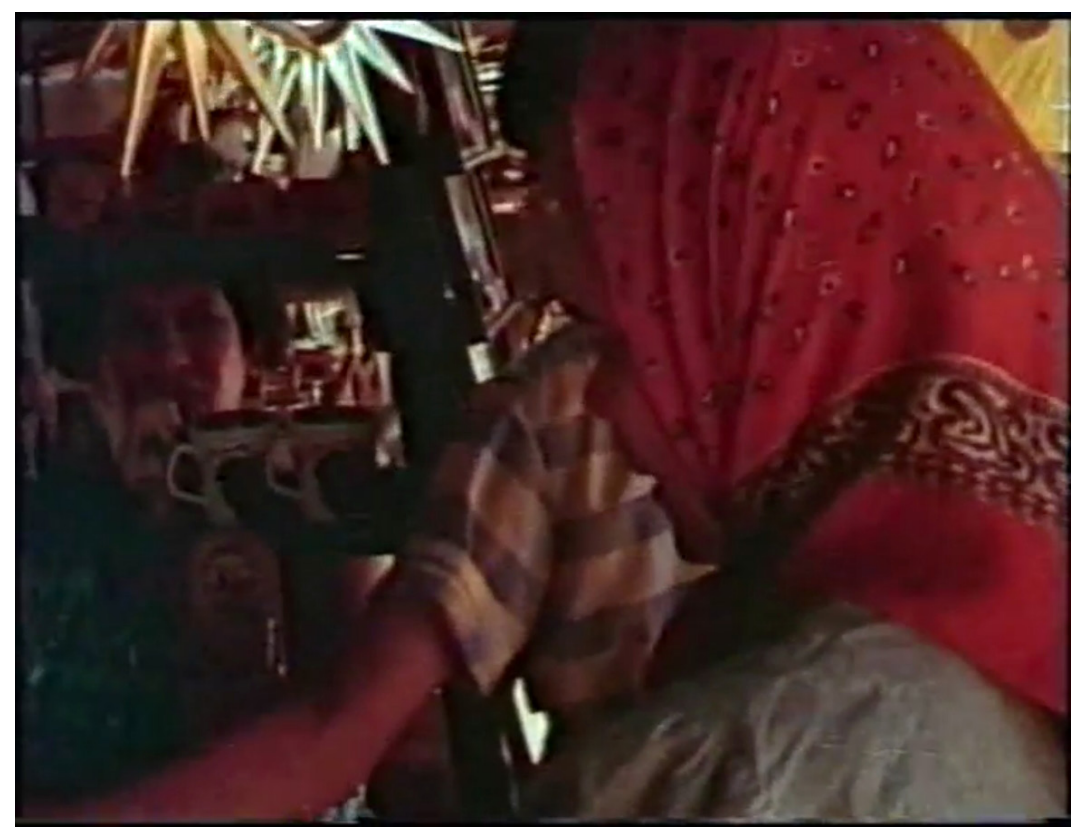

Fuente: Fotograma capturado de En busca de San La Muerte (Ott y Molina y Vedia, 1972) 
Figura 8. Construcción del punto de vista de Cándida López.

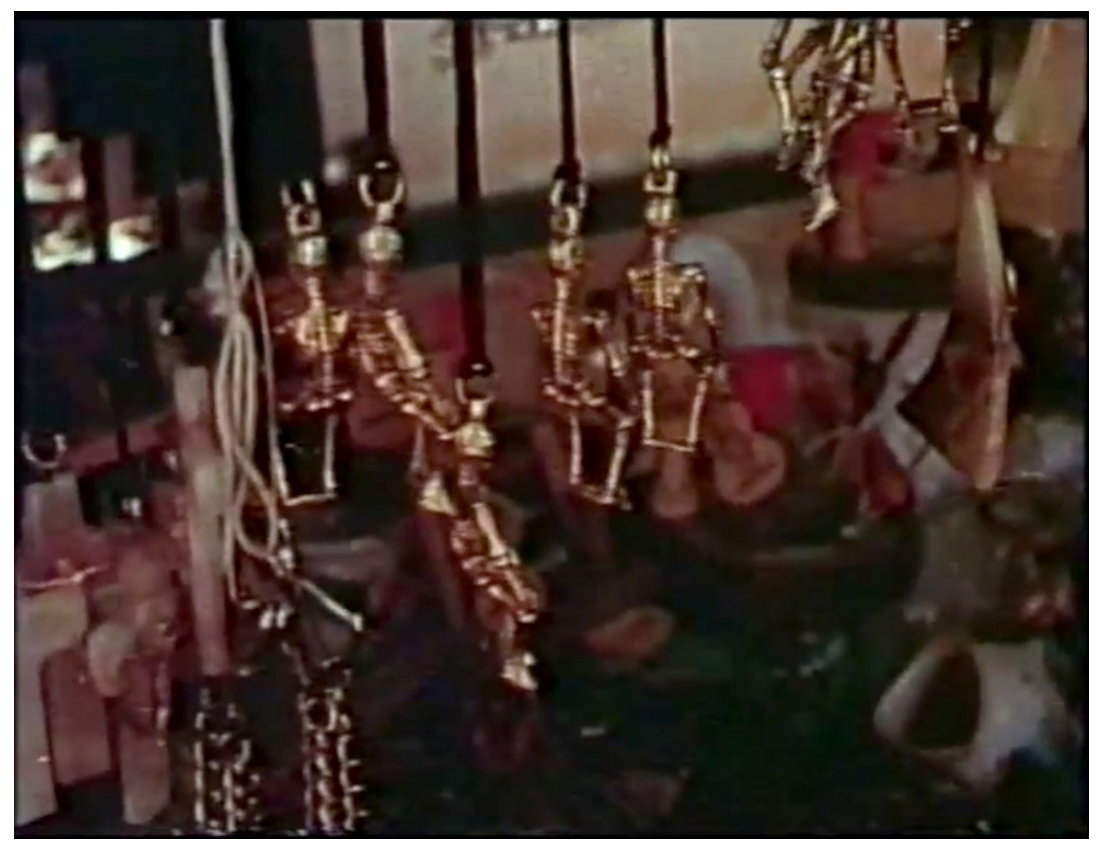

Fuente: Fotograma capturado de En busca de San La Muerte (Ott y Molina y Vedia, 1972)

La inclusión de las voces de los creyentes, es otra de las características que rompe con la mirada estática sobre la alteridad y marca un quiebre con la voz over.

Queríamos romper deliberadamente con la voz de un locutor, me parecía muy agresivo, porque se le llamaba también documental a todo lo que era publicidad de actos de gobierno, si el gobierno estaba haciendo un camino o se cortaba una cinta... una voz estentórea, tremendamente comercial, fría, siempre con el mismo énfasis. Por ejemplo Sucesos Argentinos. A ese material se lo llamaba documental, con fines propagandísticos, del cual el cine que tuviese estas pretensiones, documentar la realidad social con prescindencia de ideología política, quería diferenciarse. Ese era el cine que yo hacía o la escuela de Santa Fe. Fue Prelorán el que introdujo esa variante en el terreno documental, usar la voz de la gente que vive la escena ${ }^{51}$.

Los relatos que se escuchan fueron hechos con recortes de entrevistas que registraron Ott y el antropólogo Miranda Borelli, en función de construir una narrativa completa sobre la historia del culto a San La Muerte. Se trata de las voces de múltiples practicantes, sin precisar ni sus nombres ni su procedencia. La cuestión de dar la voz

\footnotetext{
${ }^{51}$ Entrevista personal a J. O. Ott, 10 de Septiembre de 2019.
} 
Passarelli. Los comienzos en la producción del cine documental chaqueño: cine científico y relaciones de alteridad...

al "Otro" rompiendo la locución omnisciente sobre la imagen (como venía siendo la fórmula del cine chaqueño hasta el momento), complementa los discursos, dando un equilibrio en las relaciones de poder. "Dar la voz al pueblo, a los que no tienen voz" es lo que me dice Ott en la entrevista, llevando su relato a considerar que "No queríamos tomar como narrador al autor, el narrador tenía que ser el que creía, el que practicaba, el creyente". Como parte de esta idea, la película luego fue exhibida en los lugares donde se filmó y donde se habían registrado las voces de los practicantes, como las ciudades de Resistencia, Barranqueras, Corrientes, Itatí e Ituzaingó. A pesar de que siempre la voz predominante es la de los realizadores (ellos son los que piensan la idea, manejan la cámara, seleccionan los planos en el montaje y exhiben la película) el hecho de "conceder la voz al otro" cambia la perspectiva. ${ }^{52}$

En un punto intermedio entre ambas formas de concebir la alteridad se encuentran las obras documentales de Jorge Castillo filmadas en Súper $8 \mathrm{~mm}$ denominadas Campamentos juveniles ${ }^{53}$ (Castillo, 1973), Cacique Catán ${ }^{54}$ (Castillo, 1975) y Pinyo Olka $^{55}$ (Castillo, 1975). Cabe señalar que las últimas dos películas son proyectos inconclusos, las cuales han quedado con un montaje provisorio y sin sonido, por lo que el análisis resulta limitado. Como bien señala el título, Campamentos juveniles narra los acampes de adolescentes que se montaban en Resistencia, mientras que los otros dos cortometrajes abordan la temática indígena. Una característica constante del cine de Castillo en toda su filmografía es la transformación de los encuadres a partir de acercar y alejar el foco, en un juego permanente con las cualidades plásticas de la imagen "deformada" por este efecto. A la vez, sumado al encuadre, el montaje marcado por los cortes directos y los saltos en la continuidad, producen un ritmo vertiginoso el cual activa al espectador. El dispositivo de representación queda, en parte, revelado a través de este mecanismo y la voz del realizador explicitada. Por ejemplo en Pinyo Olka, donde se narra una obra de teatro interpretada por indígenas Qom, el encuadre está en un permanente manejo de distanciamiento y acercamiento a partir del enfoque, quizás esbozando un principio de danza y trance. El cortometraje está dividido en dos partes, donde en la primera vemos el registro de los ensayos de la obra en el barrio Cacique Pelayo, en la localidad de Fontana; y en la segunda, Castillo filma la función de estreno en el salón de actos de la Escuela Industrial $N^{\circ} 1$ de Resistencia. El público

\footnotetext{
${ }^{52}$ La otra película que filmó durante esta época Jorge Ott fue sobre el impacto que la represa de Yacyretá iba a tener con la inundación de las islas cercanas a la ciudad de Ituzaingó. Con el auspicio del Ente Binacional y de la Secretaria de Bienestar Social de Corrientes, la película retrataba a los lugareños en su vida cotidiana. Con una metodología cercana a la etnográfica, donde convivió con la gente por un tiempo, Ott iba a filmar cómo esas islas iban a desaparecer después de la inundación generada por la construcción del megaproyecto. Si bien no tenía un carácter de denuncia, todo el material del film fue desaparecido durante la época de la dictadura y la película nunca se llegó a montar.

${ }^{53}$ Digitalizada. Duración: 9:46. Soporte: Súper 8mm. Formato: Color. Locución: Ercilio Castillo. Material Sonoro: Luis Nachón. Dirección: Jorge Castillo.

${ }^{54}$ Digitalizada. Duración: 2:49. Soporte: Súper 8mm. Formato: Color. Colaboradores: Luis Bernardo Nachón y Guillermo Zapiola. Dirección: Jorge Castillo. Filmada en el año 1975, fue re-editada en el 2019 en formato digital por el propio Castillo.

${ }^{55}$ Dos hermanos perdidos. Digitalizada. Duración: 9:46. Soporte: Súper 8mm. Formato: Color. Dirección: Jorge Castillo.
} 
que observa la obra es parte de la representación tanto en la comunidad indígena donde se practican los movimientos como en la presentación en la Escuela, frente a indígenas y no-indígenas. El punto de vista de la enunciación se involucra en el campo, lo cual hace que la perspectiva expositiva cambie y la cámara se sumerja en los acontecimientos. Como mencionaba al comienzo del análisis resulta fundamental mencionar que es un proyecto inacabado, faltando el montaje del sonido con las palabras y canciones en lengua Qom, que acompañan las danzas y acciones de los actores. Según el propio Castillo: "el filme no tendría ni locución ni carteles explicativos; simplemente mostraría la experiencia tal como se la registró y la reacción del público y actores, como dando lugar a un debate posterior". ${ }^{56}$

En Cacique Catán, la cámara funciona de la misma manera pero actuando de forma distante y sin tanto movimiento. El cortometraje es de muy breve duración y narra el velatorio del Cacique Catán, quien fue un conocido líder de la comunidad Moqoit. Con el uso de intertextos, recortes de diarios y fotografías como presentación del tema (todo esto agregado en la re- edición del año 2019), las imágenes luego focalizan en el registro del momento desde las caras, los perfiles y los planos conjuntos, a modo descriptivo. Como parte de la voz de Castillo en el film, aparece el viaje y las incidencias que tuvieron que pasar. Se trata de un accidente con el auto que tuvo el director a la vuelta del recorrido, el cual queda registrado en el cuerpo del relato. Así, los cortometrajes documentales de Castillo, sugieren una novedad experimental en la cinematografía local pero manteniendo algunos de los presupuestos del modelo reparacionista- reivindicatorio.

Por último, encontramos las películas en Súper $8 \mathrm{~mm}$ realizadas por "Cacho" Belsky, abordando la Fiesta del Inmigrante en la ciudad de Las Breñas. Se trata de cinco películas, las cuales son Caminante, no hay camino (1975), Capital del Inmigrante (1976), Seguir haciendo Chaco (1978), El breñal fue hace tiempo (1978) y Donde vive la esperanza (1980). Las primeras tres desde estrategias documentales y las últimas dos combinando la ficción y el documental, centran su atención en las diferentes instancias de la fiesta, como el desfile de carrozas, la elección de la "reina", las actividades de los niños y los discursos oficiales de los políticos. La diferencia aparece marcada por la diversidad de las colectividades, que asientan sus nacionalidades a partir de la performatividad de danzas, alimentos, carrozas y vestimentas, entre otras. Por ende, hay una asociación directa entre nacionalidad y cultura al vincular, por ejemplo, a la colectividad alemana con la cerveza, a la griega con la diosa Palas Atenea o a la rusa con los bailes cosacos. A pesar de la marcada variedad cultural que indican los límites de las comunidades, en la mirada de "Cacho" Belsky hay un reconocimiento y una identificación con la fiesta en general, unidos por la palabra "inmigrante". Todas las colectividades se reconocen como inmigrantes y el director, al formar parte, se enmarca en la totalidad. No hay distancia entre el director y los sujetos filmados, la empatía se hace notoria y la cámara se desplaza con seguridad por todo el evento.

\footnotetext{
${ }^{56}$ Comunicación personal con Jorge Castillo 05 de Octubre de 2020.
} 
Passarelli. Los comienzos en la producción del cine documental chaqueño: cine científico y relaciones de alteridad...

La Fiesta del Inmigrante en los films, está contextualizada dentro del amparo estatal, donde interviene en varias ocasiones la palabra del intendente, así como se remarca la construcción de caminos, la instalación del Banco del Chaco en el pueblo, las nuevas luminarias de la ciudad y la "prolijidad" del espacio público. Junto a esto también se reivindica el trabajo en el campo y el proceso de colonización que llevaron adelante los inmigrantes. La idea de "progreso" y "modernización" está notablemente marcada en las películas, dando cuenta de un proceso de avance sobre los territorios "desérticos". Muchas de estas características aparecen en los films durante la época de la última dictadura militar.

\section{Conclusiones}

A lo ancho de la historia de este primer momento de la cinematografía chaqueña, hemos focalizado en dos grandes puntos del abanico de films, como son la producción y la representación. Con respecto al primero, dimos cuenta de un escenario de producción que comenzaba a consolidarse, a partir de las redes de confianza, el trabajo grupal y el apoyo de la UNNE. Queda planteado para futuros trabajos indagar con mayor profundidad en estas redes con el fin de descubrir nuevos vínculos y a la vez, proyectar el análisis durante la época de la dictadura. Desde 1976 el cine chaqueño continuó su desarrollo y producción, a contrapelo de lo que venía pasando en la cinematografía nacional y esto amerita una investigación aparte. En relación a la dimensión representacional de los films, propusimos dos categorías a las que llamamos "cine científico" y "cine de la diferencia" como un primer intento por agrupar las producciones. Sin lugar a dudas que estas mismas películas se pueden pensar desde otras categorías y alentamos a seguir explorando las continuidades y las diferencias entre los pioneros cortometrajes chaqueños. Además, urge un análisis comparativo con el resto de los films producidos por universidades nacionales durante el mismo periodo, para ver cómo estas imágenes se expandieron y se modificaron según cada institución.

Para concluir, pensamos que filmar desde la provincia o desde la región significa visibilizar equipos de producción, pantallas, recursos y estudios, atravesados por la historia; significa instancias de aperturas en la producción donde los jóvenes aprenden de iluminación, cámara, sonido y montaje en la localidad; se trata de modos de representación que, por más que algunas sigan repitiendo cánones, otras buscan la innovación y experimentación; se trata de abordajes de temas y problemas locales; se trata de pantallas nuevas, promoviendo la emergencia de espacios de exhibición. Las discusiones sobre cine provincial y regional entonces, implican una visibilización en los distintos niveles de construcción de las imágenes, desde que se piensa la idea del film hasta que se exhibe, comprometiendo al tejido social que las envuelve.

Todos los films presentados contribuyen a delinear la imagen de la provincia y de la región, a partir de las representaciones de los sujetos y los paisajes. Se trata de estudiar críticamente los caminos y las historias de estas nuevas (viejas) imágenes para dar cuenta de contextos más amplios, marcados por la desigualdad. Por lo tanto, los conceptos de "cine regional" y "cine provincial" siguen en constante construcción y discusión. Lo 
importante para remarcar es que no son conceptos homogéneos y totalizadores, sino, por el contrario, incluyen una variedad de formas, discursos y posturas políticas y éticas al interior de los mismos que no debemos prescindir. Justamente se trata de no fijar una mirada a una provincia o región, sino de ver las disputas en el fondo de las mismas, explicitar sus posicionamientos y enlazarlos con los contextos sociales donde se han desarrollado. Volviendo a las preguntas iniciales, se trata de ver quiénes hablan, de qué forma lo hacen, bajo qué discursos y con qué medios, para repensar la historia audiovisual del Chaco.

\section{Referencias bibliográficas}

Aumont, J. y Michael M. (2006). Diccionario teórico y crítico del cine. Buenos Aires: La Marca.

Barrios C. y Arancibia V. (2017). “Audiovisual y región: reflexiones interdisciplinares. Primera parte." Folia Histórica del Nordeste. 30. 53- 64.

Benedetti, A. (2008) "Los usos de la categoría región en el pensamiento geográfico argentino". Scripta Nova. Revista Electrónica de Geografía y Ciencias sociales, Barcelona, Universidad de Barcelona, vol. XIII, No 286, Recuperado de: http:// www.ub.es/geocrit/sn/sn-286.htm

Bienvenido, León (2008) “El documental científico y sus coordenadas". Quaderns del $C A C, 30,11-18$

Bradford, M. L. (2018). "Génesis, paraíso e infierno. Un análisis de El jardín de las delicias de Arturo Fabiani”, Folia Histórica del Nordeste, 31, 65-78.

Bordwell, David. (1996). La narración en el cine de ficción. Madrid: Paidós.

Bovisio, M. A. (2013). "El Dilema de las Definiciones Ontologizantes: Obras de Arte, Artefactos Etnográficos, Piezas Arqueológicas”. Caiana Revista de Historia del Arte y Cultura Visual Centro Argentino de Investigadores de Arte, 3, 1-10.

Castillo, J. (2003). Cine argentino e identidad cultural. Gráfica Kracos: Resistencia.

Cuarterolo, A. (2013). De la foto al fotograma. Relaciones entre cine y fotografía en la Argentina (1840-1933), CDF Ediciones: Montevideo.

Cuarterolo, A. (2015). "El cine científico en la Argentina de principios del siglo 20: entre la educación y el espectáculo". História da Educação, 19(47), 51-73.

Cossalter, J. (2019) "La producción audiovisual contemporánea en Chaco y las leyes de fomento. Expansión local y alcances en la región del NEA”. Imagofagia, 20, 321-349.

Fernández Silva, A. (2020). "Subversiones al binarismo heteronormativo. Diversidad sexo-genérica-identitaria en El jardín de las delicias". En: C. Barrios. Otras pantallas, luchas diversas. Reflexiones sobre la producción audiovisual del Norte argentino. Ed. Instituto de Investigaciones Geohistóricas, CONICET/UNNE: Resistencia.

Giordano, M. (2004). Discurso e imagen sobre el indígena chaqueño. Al Margen: La Plata. 
Giordano M. y Gustavsson A. (2012). "Entre la narrativa de viaje y el discurso antropológico. La primera filmografía en el imaginario del indígena chaqueño". En M. Giordano, L. Sudar Klappenbach y R. Isler Duprat. Memoria e imaginario en el Nordeste Argentino. ". Ed. Prohistoria: Argentina.

Guarini, C. (1985). “Cine antropológico: algunas reflexiones antropológicas”. En A. Colombres. (comp) Cine, Antropología y Colonialismo Buenos Aires: Ediciones del Sol- CLACSO.

Kohen, H. (2009) “El último malón”. En Mosaico Criollo. Antología del Cine Mudo Argentino, Buenos Aires Museo del Cine Pablo Ducrós Hicken, 12-17.

Leoni, M. S. (2010). "Ramón Tissera, entre historia y política en la provincia del Chaco". Revista Escuela de Historia, 9(1-2).

Leoni, M. S.y Solís Carnicer M. (2018). "Los procesos de regionalización en el nordeste argentino en las décadas de 1960 y 70: el aporte de las ciencias sociales”. Revista TEL. Tempo, Espaço e Linguagem, 1 (9), 32-43.

Nichols, B. (1997) La representación de la realidad. España: Paidós.

Ortega, M. L. (2002) Imágenes, conocimiento y educación. Reflexiones desde la historia de la representación visual en las ciencias. No 31: Cultura audiovisual y educación.

Ratier, Hugo. (2010). La antropología social Argentina: su desarrollo. Publicar. 8 (9). s.p.

Soler, C. (2017). “"Enfocar nuestra trinchera'. El surgimiento del cine indígena en la provincia de Chaco (Argentina)". Folia Histórica del Nordeste, 28, 71-97.

Zarini, M. E. (2016) "Imágenes de lo real. El cine científico argentino como cine de atracciones. Aproximaciones preliminares." En: Actas de las IV Jornadas Internacionales y VII Nacionales de Historia, Arte y Politica. Ed: Javier Campo; María Amelia García. 1. Universidad Nacional del Centro de la Provincia de Buenos Aires: Tandil.

\section{Fuentes}

Filmografía utilizada

Establecimiento Cinematográfico Martínez y Gunche (productores) y Martínez de la Pera y Gunche (directores). (1920). La mosca y sus peligros. País: Argentina.

Gallo, M. (productor y director). (1921). La sifilis y sus consecuencias. País: Argentina. Moglia Barth, L. (productor y director). (1928). La higiene en el matrimonio. País: Argentina.

Sin Información sobre la productora y Vidarte, J. C. (director). (1955). Cosecheros. País: Argentina.

Provincia del Chaco (productora) y Fernández Pissano, Á. (director). Bajo el signo del camino (1962). País: Argentina.

Chaco Gualamba (productora) y Fernández Pissano, Á. (director). (1963). El camino de la verdad. País: Argentina.

Universidad Nacional del Nordeste (productora) y Vidarte, J. C. (director). (1964). Leguminosas. Serie 2. País: Argentina 
Universidad Nacional del Nordeste (productora) y Vidarte, J. C. (director). (1965). Recuperación de suelos salitrosos País: Argentina

Universidad Nacional del Nordeste (productora) y Vidarte, J. C. (director). (1965). Una revolución pacífica País: Argentina

Universidad Nacional del Nordeste (productora) y Vidarte, J. C. (director). (1965). Esteros y cañadas País: Argentina

Universidad Nacional del Nordeste (productora) y Vidarte, J. C. (director). (1966). Inundaciones. País: Argentina

Sin Información sobre la productora y Vidarte, J. C. (director). Operativo titus (1967). País: Argentina

Sin Información sobre la productora y Vidarte, J. C. (director). Carnaval para vivir (1969). País: Argentina

Universidad Nacional del Nordeste (productora) y Vidarte, J. C. (director). (1970). Nitrógeno. País: Argentina

Universidad Nacional del Nordeste (productora) y Vidarte, J. C. (director). (aprox. 1970). La Escuela, medio conservacionista País: Argentina

Universidad Nacional del Nordeste (productora) y Vidarte, J. C. (director). (1972). Oscar Medina, artesano. País: Argentina.

Universidad Nacional del Nordeste (productora) y Ott, J. O. y Molina y Vedia M. (directores). (1972). En busca de San La Muerte. País: Argentina.

Castillo, J. (productor) y Castillo, J. (director). (1973). Campamentos juveniles. País: Argentina.

Universidad Nacional del Nordeste (productora) y Ott, J. O. (director). (1975). Docencia e investigación en el complejo técnico social. País: Argentina.

Universidad Nacional del Nordeste (productora) y Ott, J. O. (director). (1975), Vivir puede ser hermoso. País: Argentina.

Castillo, J. (productor) y Castillo, J. (director). (1975). Cacique Catán. País: Argentina. Castillo, J. (productor) y Castillo, J. (director). (1975). Pinyo Olka. País: Argentina.

Fiesta del Inmigrante (productora) y Belsky, I. (director). (1975). Caminante, no hay camino. País: Argentina.

Fiesta del Inmigrante Las Breñas (productora) y Belsky, I. (director). (1976). Capital del Inmigrante. País: Argentina.

Fiesta del Inmigrante Las Breñas (productora) y Belsky, I. (director). (1978). Seguir haciendo Chaco. País: Argentina.

Fiesta del Inmigrante Las Breñas (productora) y Belsky, I. (director). (1978). El breñal fue hace tiempo. País: Argentina.

Fiesta del Inmigrante Las Breñas (productora) y Belsky, I. (director). (1980). Donde vive la esperanza. País: Argentina.

\section{Entrevistas consultadas}

Entrevista a J. C. Vidarte en el artículo Proyección de la labor de Vidarte: cineasta integrado a nuestro Chaco, 26 de Noviembre de 1969, El Territorio. s.p.

Entrevista en el programa televisivo Nuestro Cine, O. Cerrutti, 1985. 
Passarelli. Los comienzos en la producción del cine documental chaqueño: cine científico y relaciones de alteridad...

Entrevista en el programa televisivo Nuestro Cine, J. C.Vidarte, 1985.

Entrevista a J. C. Vidarte en el artículo El documentalismo que todavía nos UNNE, 14 de septiembre de 2006. Norte. p. 8.

Entrevista personal a J. O. Ott, 30 de Mayo de 2019.

Entrevista personal a J. O. Ott, 10 de Septiembre de 2019.

Comunicación personal con Jorge Castillo, 05 de Octubre de 2020. 